\title{
AVALIAÇÃO DA EFICIÊNCIA DE DOIS SISTEMAS DE TRATAMENTO TÉRMICO PARA INATIVAÇÃO DA BACTÉRIA CAUSADORA DO RAQUITISMO DA SOQUEIRA EM CANA-DE-AÇÚCAR
}

\author{
ANTONIO CARLOS ARABICANO GHELLER \\ Engenholro Agrônomo
}

Orientador: Prof. Dr. OSWALDO PEREIRA GODOY

Dissertação apresentada à Escola Superior de Agricultura "Luiz de Queiroz", da Universidade de São Paulo, para obtenção do título de Mestre em Agronomia - Área de Concentração: Fitotecnia.

PIRACICABA

Estado do São Paulo - Brasil

Dezembro -1986 


\section{AGRADECIMENTOS}

- Ao PlanalsuCar/IAA - Programa Nacional de Melhoramento da Cá na-de-Acúcar pela oportunidade de participar do desenvolvimento da tecnologia canavieira no Brasil.

- Ao Engo Agro Alonso Keese Dodson, Ex-Coordenador Regional Sul do PLANALSUCAR, pelo incentivo e indicação para o curso de pōs-graduação.

- Ao Ex-Superintendente Geral do PLANALSUCAR, Dr. Nadir Almeida Gloria, pela oportunidade de realizar o curso, e a seu su cessor, Engo Agro Luiz Carlos Correa Carvalho, pela oportuni dade de concluir os trabalhos didáticos de pós-graduação.

- Ao Dr. Hasime Tokeshi, Ex-Supervisor de Melhoramento do PLANALSUCAR e aos colegas da Seção de Melhoramento da Coordenadoria Regional Sul, especialmente ao Dr. Sizuo Matsuoka, pe10 amparo técnico e institucional que permitiu a reorganizacão de toda nossa vida profissional.

- Ao Prof. Dr. Oswaldo Pereira Godoy, nosso orientador, pelo encaminhamento, compreensão e liberdade oferecidas na elaboração dos trabalhos disciplinares e da dissertação,e pela con fianca creditada de que poderiamos cumprir nossas responsabi lidades acadèmicas e técnico-científicas.

- Ao Dr. Sizuo Matsuoka e Dr. Yodiro Masuda, pela orientacão e facilidades concedidas ao desenvolvimento deste trabalho.

- Aos companheiros, Técnicos Agrícolas Antonio Paulo Mazon Mar 
chetti, Nobuyoshi 0jima, Luiz Carlos Dizeró, Francisco Rober to Pereira, Cesar Evair Ciola, pela imprescindivel atuacão nos trabalhos de campo e laboratório de fluxometria, sem a qual seria impossivel conduzir este estudo.

- Ao Biólogo José Abramo filho e Auxiliar Munira Elias Stolf, pelas leituras de microscopia de contraste de fase.

- A Engạ Agrạ Sônia Maria de Stefano Piedade pelo processamento estatístico e sugestões apresentadas, e ao Engo Agro Norberto Lavorenti pelo dimensionamento estatístico projetado.

- A Bibliotecária Ana Maria Zaia Gheller pela organizacão das citações bibliográficas e em conjunto com as Bibliotecárias Sueli A. Metzker Pereira Ribeiro e Maria Eloisa L. da Costa pelo auxilio na revisão de literatura.

- A Roseli Ap. Cressoni Sampaio e Aparecida de Lourdes Mussarelli Massaro pelos trabalhos de datilografia e revisão dos textos, e à Maria Luiza Finardi Mazetto pela redacão do resu mo na versão para o idioma inglès.

- A Fitopatologista Marineide M. Aguillera pelas sugestões e adequação do texto na lingua inglesa.

- A todos aqueles que anonimamente contribuiram para a realiza cão deste aperfeicoamento profissional, e confiaram na possi bilidade de conclui-lo oportunamente. 


\section{INDICE}

Pāgina

LISTA DE TABELAS $\ldots \ldots \ldots \ldots \ldots \ldots \ldots \ldots \ldots \ldots \ldots \ldots \ldots \ldots$

RESUMO $\ldots \ldots \ldots \ldots \ldots \ldots \ldots \ldots \ldots \ldots \ldots \ldots \ldots \ldots \ldots \ldots \ldots \ldots \ldots$

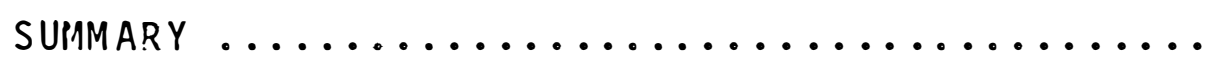

1. INTRODUCAOA....................... I

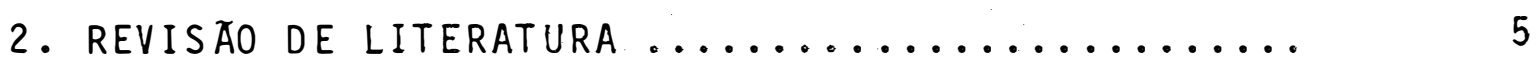

2.1. Importância econômica do RSD ........... 6

2.2. Agente causal do RSD ................ 10

2.3. Controle do RSD .................. 16

- Tipos de equipamentos para a termoterapia 18

- Controle do RSD por àgua quente ........ 20

- Equipamento de termoterapia através de

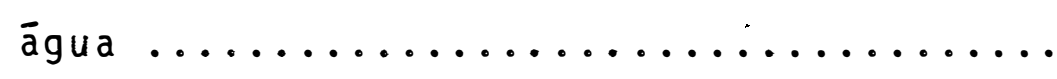

2.4. Diagnose do RSD $\ldots \ldots \ldots \ldots \ldots \ldots \ldots \ldots$

- Diagnose por microscopia de contraste de

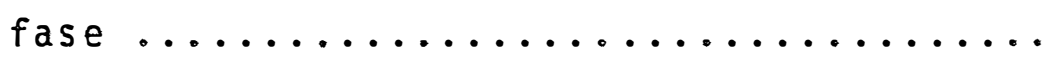

- Diagnose por fluxometria .............

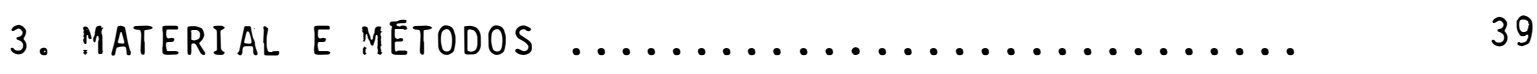

3.1. Sistemas de tratamento térmico........... 39

3.2. Variedades empregadas e obtenção das mudas tratadas $\ldots \ldots \ldots \ldots \ldots \ldots \ldots \ldots \ldots \ldots \ldots \ldots \ldots \ldots \ldots \ldots \ldots$

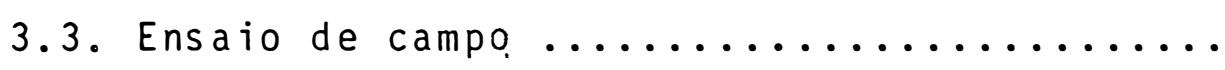

- Delineamento experimental .............

- Instalacão e conducão do ensaio no campo 
Pāgina

- Parāmetros agrícolas analisados ........ 42

- Anālises estatisticas ............... 43

3.4. Avaliação da eficiência dos sistemas ...... 43

- Fluxometria de àgua através dos colmos .. 43

- Avaliacão dos sintomas vasculares do RSD 44

- Contagem de bactérias (Clavibacter xyzi subsp. $x y z i$ ) através de microscopia de contraste de fase ................ 45

3.5. A.pēndice $\ldots \ldots \ldots \ldots \ldots \ldots \ldots \ldots \ldots \ldots \ldots \ldots \ldots \ldots \ldots \ldots$

4. RESULTADOS E DISCUSSAO $\ldots \ldots \ldots \ldots \ldots \ldots \ldots \ldots \ldots$

4.1. Avaliacão dos parâmetros agrícolas ....... 48

4.1.1. Producão de colmos por parcela ..... 48

4.1.2, Diâmetro médio dos colmos (mm) ..... 51

4.1.3. Altura média dos colmos $(\mathrm{cm}) \ldots . . .65$

4.1.4. Nümero de colmos industrializāveis 54

4.2. Avaliação da eficiência dos sistemas de tra

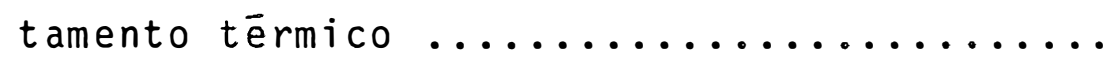

4.2.1. Fluxometria de água através dos col$\operatorname{mos} \ldots \ldots \ldots \ldots \ldots \ldots \ldots \ldots \ldots \ldots \ldots \ldots \ldots$

4.2.2. Avaliação de sintomas vasculares de

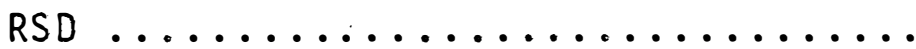

4.2.3. Contagem de bactérias (Clavibacter $x \underline{y}$ $z_{i}$ subsp. $x y z i$ ) através de microscopia de contraste de fase ......... 64

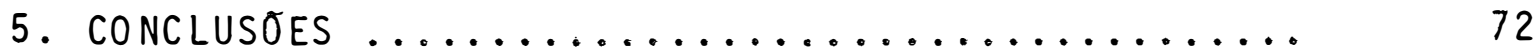


Página

6. LITERATURA CITADA $\ldots \ldots \ldots \ldots \ldots \ldots \ldots \ldots$ 73

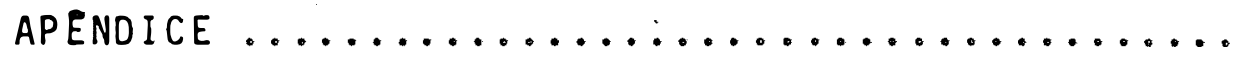




\section{LISTA DE TABELAS}

Pāgina

Tabela 1. Producão de colmos em toneladas por hectare (t/ha) e peso médio das parcelas ex perimentais ( $\mathrm{kg}$ ) em cana planta e soca de 3 variedades, com 3 tratamentos cada.

Tabela 2. Diâmetro médio entre medidas na base, meio e ponta dos colmos, em cana planta e soca de 3 variedades, com 3 tratamen-

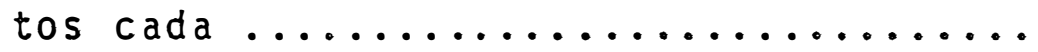

Tabela 3. Altura média em cana planta e soca de 3 variedades, com 3 tratamentos cada .....

Tabela 4. Número de colmos por hectare e número mé dio de colmos das parcelas experimentais, em dois cortes consecutivos, para 3 variedades com 3 tratamentos cada ....

Tabela 5. Medidas de fluxo de àgua através dos col mos, em mililitros por 15 minutos a $30 \mathrm{~mm}$ Hg de pressão negativa, em cana planta e soca de 3 variedades, com 3 tratamentos cada $\ldots \ldots \ldots \ldots \ldots \ldots \ldots \ldots \ldots \ldots \ldots \ldots \ldots \ldots \ldots \ldots \ldots$

Tabela 6. Avaliacão de sintomas vasculares de RSD, em cana planta e soca, observada nos col mos submetidos ao fluxo de àgua, para 3

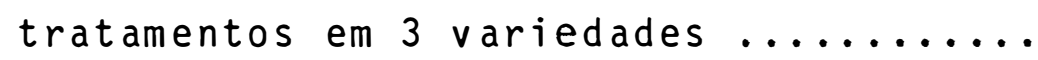


Tabela 7. Contagem de bactérias através de microscopia de contraste de fase, em extratos do xilema de colmos da variedade CB41-76, cana soca, e avaliação destes colmos para fluxo de àgua e sintomas vas

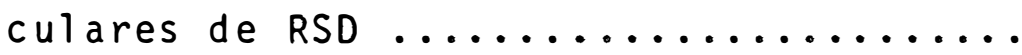

Tabela 8. Contagem de bactérias através de microscopia de contraste de fase, em extratos do xilema de colmos da variedade NA56-79, cana soca, e avaliação destes colmos para fluxo de água e sintomas vas

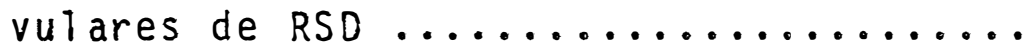

Tabela 9. Contagem de bactérias através de microscopia de contraste de fase, em extratos do xilema de colmos da variedade CB49-260, cana soca, e avaliaça destes colmos para fluxo de àgua e sintomas vas

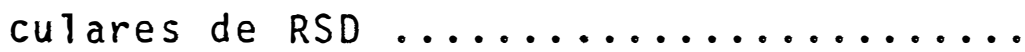




\section{RESUMO}

AVALIAÇAO DA EFICIENCIA DE DOIS SISTEMAS DE TRATAMENTO TERMICO PARA INATIVACAO DA BACTERIA CAUSADORA DO RACQUITISMO DA SOQUEIRA EM CANA-DE-ACOCAR.

Autor: Antonio Carlos Arabicano Gheller

Orientador: Prof. Dr. Oswaldo Pereira Godoy

A avaliação comparativa da eficiência dos siste mas de tratamento térmico disponíveis no Brasil para a inativa cão da bactéria Clavibacter xyzi subsp. xyzi, causadora do Raquitismo-da-Soqueira (RSD) em cana-de-acúcar, constituiu o objetivo principal deste estudo.

Foram utilizados os equipamentos que caracterizam o sistema de tratamento térmico de gemas isoladas e o sistema de toletes de três gemas, ambos com fabricação seriada. Para o tratamento térmico comparativo escolheu-se as variedades de cana-de-açúcar CB47-76, CB49-260 e NA56-79, consideradas suscetiveis ao RSD, e que se encontravam altamente infecta das, para maior clareza da manifestação de eficiência dos equi pamentos. o planejamento do trabalho definiu a avaliacão de parâmetros agricolas que pudessem ser influenciados pelo RSD tais como: produtividade agricola, diâmetro e altura mé- 
dia dos colmos, e numero de colmos industrializáveis por ārea. Como tais parämetros são fortemente influenciados pelo meio, notadamente a precipitação pluviométrica, lançou-se mão de métodos desenvolvidos mais recentemente para avaliacão do RSD que são a fluxometria de àgua atravēs dos colmos (nós) e microscopia de contraste de fase, correlacionando-os, ainda com a tradicional visualização dos sintomas internos de RSD, nos colmos. Os trabalhos de campo e laboratōrio foram conduzidos na Estação Experimental de Cana-de-Açūcar do IAA/PLANALSUCAR em Araras-SP, em cana planta e primeira soca.

os resultados confirmaram a significativa recuperação da produtividade agrícola pelo uṣo do tratamento térmi co a $50,5^{\circ} \mathrm{C} / 2$ horas em cana-de-açūcar. Na mēdia das três varie dades estudadas houve ganhos de rendimento agrícola da ordem de $17 \%$ em cana planta e $30 \%$ em cana soca, comparando-se os dados médios dos dois sistemas de tratamento térmico com as plan tas não tratadas e bastante contaminadas pelo RSD. Não houve interferéncia do RSD no nūmero de colmos industrializáveis por ārea, sendo os fatores de influéncia na produtividade agrícola o diàmetro e altura média dos colmos.

0 confronto dos parāmetros agrícolas com as me didas de fluxo de àgua atravēs dos colmos, a contagem de bacté rias por microscopia de contraste de fase e a sintomatologia vascular do RSD, com avaliacões em colmos doentes (RSD) e tratado termicamente pelos dois sistemas, possibilitou mostrar a correlacão direta e estreita entre todos os métodos empregados 
na detecção do RSD.

Concluiu-se que os sistemas de tratamento térmi co de gemas isoladas e de toletes de três gemas são igualmente eficientes na inativacão do agente causal do RSD. 
EVALUATION OF THE EFFICIENCY OF TWO HOT WATER TREATMENT SYSTEMS FOR THE INACTIVATION OF SUGARCANE RATOON STUNTING DISEASE BACTERIUM

\section{ANTONIO CARLOS ARABICANO GHELLER}

Adviser: 0swaldo Pereira Godoy

The main objective of this study was the comparison of the efficiency of two hot water treatment equipments, commercialy available in Brazil, for the inactivation of the bacterium Clavibacter xyli subsp. xyli, the pathogen of sugarcane ratoon stunting disease: the hot water treatment of single-bud setts and the hot water treatment of three-bud setts.

Highly infected seed pieces of sugarcane varieties CB41-76, CB49-260 and NA56-79, a 11 of them considered susceptible to RSD, were treated in both equipments and planted in nurseries besides untreated control plots. A year after the experiment was installed in randomized blocs, with six replications, in order to obtain a clear comparison of the efficiency of both systems.

The parameters utilized to evaluate the effi ciency of the equipments were: cane yield, number of millable 
stalks, diameter and average height of stalks, in treated and untreated plots. As these parameters may be strongly influenced by the environment, mainly rainfall, the evaluations were complemented by other methods, recently developed to evaluate RSD, i.e., measurement of water flux through the stalks nodes and phase contrast microscopy to detect the bacterium. Also, these evaluations were compared to the traditional evaluation of RSD by the internal symptons of the disease.

Field and laboratory experiments were carried out at IAA/PLANALSUCAR - Sugarcane Experiment Station at Araras $-S P$, in plant cane and first ratoon.

As expected, the hot water treatment at $520 \mathrm{C} /$ 2 hours, whichever the method used, promoted significant recovery of cane yield in the three varieties, with an average increase of $17 \%$ in $\mathrm{plant}$ cane and $30 \%$ in the first ratoon. The disease did not interfere on the number of millable stalks per area. The influence observed were on the diameter and average stalk height.

The water flux method, the phase contrast microscopy and the internal symptom observation correlated welt among them, no matter whether the cane was highly infected or with residual infection after the hot water treatment.

It was concluded that the heat treatment of single-bud and three-bud sett systems are equally efficient for the inactivation of the RSD causal bacterium. 
1. INTRODUÇAO

Apesar da grandiosidade atual do conjunto agroindustrial canavieiro do Brasil, o que o coloca como o maior produtor mundial de cana-de-acúcar e ālcool, o crescimento horizontal da fronteira agricola canavieira para condicões de so 10 e clima nunca explorados em cana-de-açucar, bastante incentivada a partir de 1975 pela criacão do Programa Nacional do Alcool - PROÁLCOOL, vem acompanhado de problemas que são refle tidos na baixa produtividade média $(54 \mathrm{t} / \mathrm{ha})$. Mesmo Estados mais tradicionalmente produtores como São Paulo, onde estão 10 calizados 2 dos 4 milhões de hectares de cana-de-açúcar do Bra sil, apresenta produtividade agrícola média de 62 t/ha cultiva do, bastante abaixo do potencial real de producão já viabiliza do por algumas unidades produtoras melhor administradas. 
A tendência de se buscar aumento da produtivida de agroindustrial sugere investimentos na tecnologia de producão e principalmente redução de perdas. Dentre os fatores que determinam perdas, as doencas da cana-de-açūcar situam-se como dos mais importantes. A prōpria histōria da lavoura canavieira no Brasil mostra exemplos dessa afirmacão com as epidemias sucessivas de gomose da cana-de-acucar por volta de $1860-1880$, de mosaico em 1922, e a constatação e medidas de controle do carvão a partir de 1951, com severos prejuizos aos produtores canavieiros. As doenças de natureza endēmica, entretanto, têm provocado perdas constantes, notadamente na atual expressão da ärea cultivada em cana-de-açucar. Entre essas doencas destacase o raquitismo da soqueira, considerada indubitavelmente a doenca mais importante da agroindūstria canavieira mundial.-

STEINDL (1961) considera que o raquitismo da so queira, conhecido mundialmente como "ratoon stunting disease" - RSD, tem causado mais prejuizos aos paises canavieiros, nos $\bar{u} l t i m o s$ anos, que todas as outras doencas da cana-de-açucar.

Quando da descoberta do RSD, na Austrátia, a termoterapia, utilizada até então para controlar outras doeñcas, foi a opcão natural para o controle do RSD. Dada à eficiência demonstrada, o tratamento térmico passou a ser largamente utilizado pelos paises canavieiros.

Embora muitas empresas canavieiras tivessem ado tado o tratamento térmico para o controle do RSD, a partir de equipamentos de fabricacão pröpria, no Brasil a termoterapia 
só passou a ser utilizada intensivamente com o dimensionamento do sistema de termoterapia de gemas isoladas feito pela COPERSUCAR (SILVA, 1976). Posteriormente, TOKESHI et alii (1983) de senvolveram o equipamento para tratamento térmico de toletes de três gemas, e atualmente ambos os modelos estão sendo utili zados pelos produtores.

A termoterapia pode ser realizada por diferentes tipos de equipamentos, desde que seja de real eficiēncia na inativação do agente causal do RSD. BENDA e RICAUD consideram que o sistema de tratamento térmico pode ser modifi cado para aceitar gemas isoladas, colmos inteiros ou toletes.

Dada às diferentes caracteristicas dos equipamentos para tratamento térmico disponiveis em fabricacão seria da no Brasil, e em razão das profundas diferencas de concepcão, operação, volume de colmos tratados, tempo para atingir o plantio dos viveiros iniciais, custos dos equipamentos e da operacionalizacão dos sistemas funcionais (gemas isoladas ou toletes de 3 gemas), têm surgido, com frequência, dūvidas sobre qual sistema adotar, principalmente quanto $\bar{a}$ eficiēncia comparativa entre eles. A resposta dessa questão constitui o objetivo do presente trabalho.

As dificuldades de diagnose precisa do RSD, devido aos diversos fatores envolvidos tais como caracteristicas varietais, condições climāticas, estado fisiológico da planta e presenca de outras doencas, contribuiram para a impossibilidade de se avaliar os dois sistemas de tratamento térmico, com 
suficiente precisão, principalmente quando o agente causal ocorresse em baixa intensidade de infeccão. A partir do desenvolvimento da avaliacão do RSD via fluxometria, via microsco pia de contraste de fase e associando-se ainda os sintomas diagnósticos vasculares da doença e as características dos parâmetros agrícolas afetadas pela doença e recuperados por ambos os sistemas de tratamento tērmico, conseguiu-se instrumental de apoio técnico para o objetivo de se elucidar a questão então existente, sobre a eficiência de eliminacão do RSD em ca nas tratadas a partir do sistema de tratamento térmico de gemas isoladas e a partir do sistema de tratamento térmico de to letes de três gemas. 


\section{REVISAO DE LITERATURA}

0 raquitismo da soqueira (RSD) da cana-de-açucar foi inicialmente observado na Austrālia, nos anos de 194445, incidindo na entāo nova e promissora variedade Q28. Apōs uma primavera com baixa precipitacão pluviomētrica, vārios cam pos ou parte de alguns campos da Q28 apresentaram péssimo desenvolvimento das soqueiras, quando comparados a soqueiras pró ximas da mesma variedade (STEINDL, 1961). Em pouco tempo este mesmo autor definiu, apōs testes experimentais, que o RSD era uma doenca transmissivel que poderia ser espalhada artificialmente pelos instrumentos de corte da cana-de-acúcar, contamina dos por extratos de plantas doentes.

Embora tenha sido caracterizada primeiramente na Austrälia, nada se pode afirmar quanto à origem do RSD. 
STEINDL (1961) considerou que o RSD existiu sem ser detectado por muitos anos e foi transferido entre paises canavieiros atravēs das trocas de variedades. A partir da caracterização do RSD em 1949, relatos sucessivos acusaram a ocorrēncia na maior parte dos paises canavieiros. HUGHES (1978) considerou que, devido à dificuldade de identificação, fosse provāvel que - RSD ocorresse onde quer que a cana-de-açūcar fosse cultivada. KING (1954) definiu O RSD como responsável pela citada "degenerescência" que a cana-de-açūcar apresentava após anos de utilização sucessiva, de causa não determinada ou considerada de natureza genētica.

No Brasil, O RSD foi constatado em 1956 pelo pesquisador F.M. Veiga, em Campos-RJ e por Bento Dantas no Estado de Pernambuco, conforme citações de MATSUOKA (1971b). Este autor considera a doença disseminada generalizadamente por todos os canaviais do Brasil, atualmente.

2.1. Importância econômica do RSD

A importāncia do RSD em cana-de-açūcar deve ser atribuida a trēs fatores fundamentais: pelas perdas que provoca, pela dificuldade de ser detectada em face da inexistencia de sintomas externos evidentes, e por ültimo, pela inexistência de controle atravēs de variedades resistentes.

TOKESHI (1980) acrescentou ainda que a doenca sofre influência de fato res ambientais principalmente regime de chuvas, evapotranspira 
cão, tipo de solo, podridões de raizes, e tolerāncia varietal. HUGHES (1974) definiu as perdas causadas pelo RSD como dependentes da tolerância das variedades e disponibilidade de àgua no solo, variando porisso de pequena a severa intensidade. 0 mesmo autor classificou as perdas por RSD em dois grupos: perdas indiretas (emergencia e perfilhamento defi cientes, cultivos extras nas canas planta e soca, maior custo da colheita devido à menor produtividade agrícola e à presença de plantas daninhas e menor longevidade das lavouras), e perdas diretas (menor producão com canas planta e soqueiras, menor nümero de cortes e custos atribuîdos às necessidades de controle da doença); somente com reducão da produção em um ano, em regiões mais secas da Austrälia, estimou-se em $30 \%$ as perdas provocadas pelo RSD.

Onde quer que o RSD seja estudado em relação aos prejuizos que provoca, evidencia-se a importāncia da doenca. MATSUOKA (1976) utilizando colmos tratados em equipamento convencional de 10.000 litros de água, demonstrou ganhos de $19 \%$ e $32 \%$ para as variedades CB $41-76$ e CB49-260, respectivamen te, em média de cana planta e primeira soca, quando comparadas com colmos que não foram tratadas termicamente; is to representou produtividades adicionais de $16 \mathrm{t} / \mathrm{ha}$ e $25 \mathrm{t} / \mathrm{ha}$, respectiva mente. Ainda no Estado de São Paulo, MATSUOKA (1984b) voltou a apresentar resultados expressivos do efeito do RSD na producão agricola da cana-de-açúcar, traduzidos pela demonstracão de perdas de $16 \%, 24 \%$ e $37 \%$, para as variedades CB $41-76$, CB $49-260$ 
e IAC52-326, respectivamente, considerando-se trēs cortes sucessivos. No Estado de Pernambuco, IAA/PLANALSUCAR (1976) apre sentou o RSD como fator de perda de $16 \%$ em acuucar, quando comparadas plantas doentes e sadias da variedade Co331, uma das mais cultivadas em Pernambuco e tambēm no Estado de Alagoas.

Em outros países, as avaliações de prejuízos causados pelo RSD é bastante coerente com os dados produzidos no Brasil. STEINDL (1961) citou para diversas variedades testa das na Austrāila, perdas de $10-15 \%$ em cana planta e 20-25\% em cana soca; como efeito normalmente comprovado. 0 mesmo autor informou que em āreas com irrigação normal e sub-irrigadas do Havai, em colheitas de canaviais com ciclo de 25 meses, verifi cou-se diminuição de produção de $14,7 \%$ (irrigação normal) e $33,6 \%$ (sub-irrigação). Na Africa do Sul avaliaram perdas na producão agrícola da ordem de 10 a $25 \%$ na variedade mais plantada, NCo376. (DROUGHT... 1980).

Ainda STEINDL (1961) definiu a redução da prodü cão agrícola principalmente devido à ocorrēncia de colmos mais finos e curtos do que propriamente à redução do nümero de colmos, embora num ano seco o número de colmos fosse também reduzidos e com muita irregularidade no comprimento dos colmos da touceira. Observou-se que o "raquitismo" caracteristico da doença não é uniforme entre touceiras, e talhões doentes mostram crescimento irregular. Melhorias na técnica cultural como maior profundidade do preparo do solo, cultivos intensivos e fertilização extra não reduziram o efeito do RSD. Entretanto, 
irrigacōes adequadas, notadamente no estādio inicial do cresci mento, tende a prevenir perdas principalmente em primeiro corte e em variedades bastante suscetiveis. 0 mesmo autor considerou que o RSD tem pequeno efeito no conteūdo de açūcar do colmo, embora existam informações de que o colmo doente tem pe quena porcentagem a mais de sacarose que a sadia, o que pode-. ria ser atribuido ao crescimento mais vigoroso deste colmo sadio.

SINGH (1974) estudou as características da produção de dez variedades de cana-de-açúcar com e sem RSD e chegou aos resultados seguintes sobre o efeito prejudicial causado pela doenca: menos $27,5 \%$ na porcentagem de germinacão; menos $25,5 \%$ no nümero de touceiras; menos $31,5 \%$ no nümero de co 1 mos industrializāveis; menos $9 \%$ na média do nümero de colmos por touceira; menos $36,5 \%$ no peso médio dos colmos; menos $4,1 \%$ no peso médio por colmo; menos $6,7 \%$ no comprimento médio por colmo; menos $3,5 \%$ na extracão de caldo; menos $3,7 \%$ no brix; me nos $5,2 \%$ de sacarose e menos $1,2 \%$ na pureza. Concluiu que o RSD tem pequeno efeito no conteúdo de sacarose, sendo as perdas na produção agrícola as principais responsāveis pela diminuição de acūcar na àrea cultivada.

Embora existam muitos dados sobre os prejuizos causados pelo RSD na produção agrícola, poucas informações caracterizam os fatores da produção envolvidos no processo das perdas. E evidente que a complicacão de anălise dos fatores de produção agrícola existe e é provocada pela grande interacão 
solo $x$ planta $\times$ clima, que interferem significativamente nos resultados comparativos entre colmos com RSD e colmos sadios. Estes fatos definem também, a impossibilidade de, somente com paraametros de natureza agrícola ou derivados dós fatores que definem a producão agrỉcola, avaliar-se comparativamente colmos com diferentes graus de contaminacão pelo RSD, notadamente quando essa contaminação ocorre em baixo nível, como é o caso de colmos submetidos à operação de controle. Consequentemente fica impossivel avaliar-se corretamente técnicas ou equipamentos diferentes de controle do RSD, apenas com avaliacão das perdas provocadas pela doença na produção agrícola.

\subsection{Agente causal do RSD}

STEINDL (1961) considerou o agente causal do RSD como sendo um vírus, devido ao insucesso das tentativas de isolamento desse agente causal, ausência de microrganismos em estudos microscópicos, tolerância à diluição do caldo contaminado e ao modo de transmissão da doença.

FORBES e LING (1960) observaram em microscopia eletrōnica, particulas de dois tipos associadas a extratos de folhas com RSD. Não observaram as mesmas particulas em extratos de folhas sadias. Sugeriram que tais particulas eram do vi rus causador do RSD. Embora outros métodos de deteccão de viro ses de plantas como absorcão ultravioleta, eletroforese, tes tes serológicos e testes colorimétricos tenham todos falhados para demonstrar a presença do virus em tecidos vegetais com 
RSD, isto não provocou dūvida sobre a natureza virōtica do agente causal do RSD (STEINDL, 1961).

GILLASPIE et aliz (1966) adotando técnicas particulares de clarificacão e centrifugacão de caldo de cana e centrifugação com gradiente de densidade admitiram o isolamento do agente causal do RSD, que aparentemente seria um virus esférico de tamanho indeterminado.

TEAKLE (1974) concluiu que a correlação entre in fecção e alguma particula semelhante a vïrus não tinha sido demonstrada, sendo portanto, inconvincentes as associações nesse sentido. GILLASPIE et alii (1967) concordaram que o agente causal do RSD teria algumas propriedades de virus, mas nenhuma que o caracterizasse por técnicas físicas ou químicas, sendo portanto coerente a indagacão que despertada entre os pesquisadoresse 0 RSD era realmente causado por um vïrus.

PLAVSIC-BANJAC E MARAMOROSCH (1972) detectaram pequena bactéria ou algo semelhante a micoplasma no xilema de entre-nós de colmos velhos e infectados vindos de porto Rico. organismos parecidos não foram observados em plantas sadias ou plantas doentes jovens. Posteriormente MARAMOROSCH et alii (1973) utilizando microscopia eletrōnica em colmos também vindos de Porto Rico, mostraram que o xilema dos entre-nós continham microrganismos parecidos com pequenas bactérias ou riquét sias. Nenhuma particula semelhante a virus ou micoplasma foi observada, e o floema estava livre desses organismos.

TEAKLE et alii (1973) encontraram uma pequena 
bactēria constantemente presente em suco fibrovascular de col mos com RSD, na Austrália. Como nunca foi observado tal bactéria em extratos de plantas livres de RSD, sugeriram que essa bactéria poderia ser o provāvel agente causal do RSD.

TEAKLE (1974) mostrou que a mesma associação es pecĩfica observada anteriormente, foi observada em colmos provenientes de cinco outras localidades da Austrāila, bastante separadas entre si. Concluiu que os microrganismos observados no material proveniente de Porto Rico (MARAMOROSCH et alii, 1973), e o material analisado na Austrália eram do mesmo tipo. Através de testes de filtrabilidade, sedimentação durante a centrifugação, reação ao calor, a produtos químicos e a antibióticos, este autor concluiu que fosse improvāvel que um orga nismo semelhante a vïrus, viróide ou micoplasma estivesse en-volvido com o RSD.

GILLASPIE et alii (1974) consideraram improvāvel que o RSD fosse provocado por micoplasma, tampouco por vīrus. Consideraram que havia bastante consistência na teoria que definia o agente causal do RSD como um organismo semelhante a bactēria.

LIU et alii (1974) encontraram organismos semeThantes a:Xanthomonas vasculorum em feixes vasculares de colmos das variedades B 49119 , Co421 e PR980. Os isolados foram identificados como a bactéria citada, atravēs de testes bioqui micos e serológicos. TOKESHI et alii (1974), através de isolamentos de bactërias coletadas em nós maduros de cana-de-açúcar 
com RSD, e com aplicação de testes bioquímicos, físicos e culturais, concluiram que havia evidências de que o agente causal do RSD fosse Xanthomonas albilineans.

A partir das associações observadas de uma bactéria como agente causal do RSD, vārios relatos passaram a evidenciar mais ainda a possibilidade de que esta premissa era verdadeira. GILLASPIE et alii (1974) apresentaram resultados obtidos a partir de estudos em microscopia de contraste de fase ou de campo escuro, filtração e purificação, que uma pequena bactéria incapaz de mover-se estava associada ao RSD. CHEN et alii (1975) relataram a ocorrēncia em Taiwan, da bactēria corineforme descrita por TEAKLE et alii (1973), encontrada em plantas com RSD das variedades NCo310 e NC064-836 e não encontradas nas plantas sadias. KAMIUNTEN e WAKIMOTO (1976) relata-ram observação constante de bactéria corineforme em xilema dos nōs de colmos de cana-de-açūcar no Japão. DAMANN e

DERRICK (1976) comprovaram a associação bactéria x RSD na Louisiana. BAILEY (1976) confirmou a associacão de organismos semelhante a bactēria e o RSD na Āfrica do Sul a partir de extratos de te cidos com RSD obtidos por difusão, utilizando diversas varieda des, em estudos com microscopia de contraste de fase e microscopia eletrónica. RICAUD et alii (1976b) relataram a observacão de bactéria corineforme em colmos com RSD em Mauritius, ad mitindo com base na sua peculiar morfologia como provavelmente sendo a mesma bactéria associada a RSD encontrada em outros paỉses. LIU (1973) descreveu a associação de pequena bactēria 
corineforme, habitante do xilema, sendo observada em caldo extraido de variedades com RSD em Porto Rico. KAISER e RAMOS (1980) encontraram pequena bactéria em caldo extraído de colmos com RSD da variedade Co421 no Quenia.

As possiveis interações entre a então provável bactēria causadora do RSD e bactērias conhecidas como $X$. vas culorum (LIU et alii, 1974) e X. albilineans (TOKESHI, et alii, 1974) foram ampliadas com o trabalho de SuDO (1980) que identi ficou a presença de outras bactērias como Erwinia herbicola e Pseudomonas rubrisubalbicans em colmos com RSD. Entretanto, RI CAUD et alii (1976b) estudando exudações de canas com escaldadura da folha, gomose e estrias cloróticas, não encontraram a bactéria normalmente associada ao RSD, sendo que as bactérias presentes eram totalmente diferentes em morfologia e tamanho.Concluiram que não hã sustentação para os relatos de que $X$. vasculorum $\mathrm{e} X$. albilineans são associadas com o RSD. DAMANN (1976) comprovou as associações de uma bactéria distinta daque las jä conhecidas e associada ao RSD, conforme informações anteriores de TEAKLE et alii (1973), GILLASPIE et alii (1974) e CHEN et alii (1975). Diversas caracteristicas marfológicas das bactērias citadas como provāveis agente do RSD foram analisadas para fundamentar a comprovacão feita. CRUZ (1983) concluiu que o agente causal da escaldadura das folhas apresenta mecanismo de patogenicidade diferente do agente causal do RSD. Foi observado que colmos submetidos aos testes de avaliaça do flü xo de āgua tinham sua vazão aumentada na presenca de escaldadu 
ra das folhas, provavelmente devido à desintegração das paredes celulares do xilema e tecido parenquimatoso adjacente.

DAVIS et alii (1980) realizaram isolamentos constantes de bactëria corineforme em cultura pura, a partir de cana-de-açūcar com RSD provenientes dos Estados Unidos, Bra sil, Africa do Sul e Japão, demonstrando ser esta bactéria o agente causal do RSD. Não foi conseguido o mesmo isolamento nos colmos considerados sadios. Bactéria semelhante foi isolada da grama-seda (Cynodon dactyzon) que, entretanto, não provo cou sintomas internos do RSD quando inoculada em cana. GILLASPIE et alii (1981), aparentemente no mesmo procedimento adotado pela referéncia anterior, descreveram os resultados dos testes biológicos e serológicos realizados para a diagnose exata dos resultados das inoculações feitas com a bactéria cul tivada, em CP44-101. Com isso conseguiu-se pela primeira vez isolar e cultivar a bactéria causadora do RSD.

DAVIS et alii (1984) estudando as bactērias encontradas em cana-de-açucar proveniente de diversos paises, e as bactērias semelhantes encontradas na grama-seda lCynodon dacty(on), propuseram sua classificacão especificada dentro do então Gēnero Corineforme. As bactērias estudadas formariam um grupo distinto e seriam reclassificadas no novo Gênero clavibacter que acomodaria as duas bactérias encontradas. Foi proposto a classificacão de Clavibacter xyli subsp. xyli sp. nov., subsp. nov. para a bactéria encontrada na cana-de-açúcar e Clavibacter $x y l i$ subsp. cynodontis subsp. nov. para a bacté- 
ria encontrada na grama-seda.

A partir dos trabalhos de DAVIS et aliz $11980 \mathrm{e}$ 1984) e GILLASPIE et alii (1981) demonstrou-se cientificamente a hipōtese de ser uma bactēria o agente causal do RSD, cuja identificacão e classificacão surge quarenta anos apōs a constatação da doença no campo.

\subsection{Controle do RSD}

0 plantio de material sadio, a prevenção da pro pagacão da doença, e o uso de variedades resistentes são as principais medidas que podem ser usadas para o controle do RSD (STEINDL, 1961).

HUGHES (1974) considerou que variedades resis tentes são essenciais para o controle de doencas na "maioria das culturas comerciais e a cana-de-açūcar não é exceção, prin cipalmente para doencas como gomose, escaldadura das folhas, carvão e outras. Entretanto, em relação ao RSD parece haver a excecão, uma vez que, aparentemente, gens para alta resistência a essa doença são extremamente raros no gênero saccharum., grau de perdas por RSD depende da tolerāncia das variedades" "a doenca e, particularmente conforme as condicões do meio ambien te, notadamente em relacão a disponibilidade de àgua no solo.

STEINDL (1974b) admitiu que o controle do RSD atravēs de variedades resistentes ainda não era praticado, existindo porém, variacões de tolerāncia nos clones comer- 
ciais. Alguns desses clones apresentariam pequenas perdas e em bora tivessem suas vantagens, poderiam ser perigosa fonte de infeccão para os clones mais suscetiveis, desde que não fossem tomadas as devidas medidas de controle.

Wismer (1971) citado por STEINDL (1974)comentou a existência de um clone, H60-6909, imune ao RSD no Havai, embora não estivesse consciente da existência de uma variedade comercial imune ao RSD.

A possibilidade de encontrar-se variedades resistentes ao RSD foi, entretanto, apresentada por STEIB e CHILTON (1968) na Louisiana, EUA, com as variedades CP52-68 e L60-25, ambas utilizadas em exploracão comercial. Estas va riedades consideradas resistentes ao RSD foram, no entanto, di zimadas pelo mosaico. A partir disso, preferencialmente, vol-tou-se a praticar outro método para controlar o RSD, utilizando a resisténcia varietal para o controle do mosaico.

HUGHES (1978) considera parecer impossive1 induzir geneticamente a resisténcia ao RSD, em variedades comerciais. Algumas variedades são mais resistentes e mais tolerantes à doenca, quando severamente infectadas, porém, a resistên cia ao RSD oferece pouca possibilidade de controle.

Os programas de melhoramento de cana-de-acūcar e competicão de variedades, tem selecionado de maneira acidental e inconsciente variedades tolerantes ou resistentes ao RSD, pois as variedades mais suscetiveis são eliminadas neste processo, conforme concluiu TOKESHI (1980). 
STEINER e COMSTOCK (1977) teceram considerações sobre a não existência de trabalhos específicos na ārea de meIhoramento genético para a resistenncia ao RSD. Os autores rela taram que em função de um programa efetivo de controle do RSD, via termoterapia, não havia desenvolvimento de esforços para seleção de variedades resistentes à doença.

Segundo considerações de SINGH (1967) quando o RSD foi diagnosticado na Austrālia e suspeitou-se ser ocasiona do por virus, a termoterapia foi a opcão natural de controle encontrada. 0 autor relata que a termoterapia foi primeiramente adotada por Kobus em 1889 em Java, quando observou que tole tes de cana-de-açucar tratados a $50-52^{\circ} \mathrm{C}$ por uma hora e meia ficavam curada da doenca sereh,e que posteriormente, Wilbrink em 1923-1932 empregou o mesmo tratamento para controle das doenças estrias clorōticas e sereh.

BENDA (1972) relatou que Sayer e Kobus testaram termoterapia para controle do sereh em 1888 e 1889 , respectiva mente. Porém, com sucesso, a termoterapia só foi utilizada 35 anos após por Wilbrink em 1923 e, a partir disso, numerosas doencas da cana-de-açucar têm sido controladas atravēs dessa técnica.

- Tipos de equipamentos para a termoterapia

Existem trés formas básicas de termoterapia para o controle (inativação) do RSD: āgua quente a 500 C por 2 
horas, ar quente a $58^{\circ} \mathrm{C}$ por 8 horas e vapor quente a $53^{\circ} \mathrm{C}$ por 4 horas. Os sistemas de áaua quente e ar quente foram dimensio nados na Austrália (STEINDL e HUGHES, 1953) e o sistema de vapor quente foi adaptado por COCHRAM et alii (1976), na Louisia na, EUA, para utilização em cana-de-açúcar.

ANTOINE (1957) considerou o tratamento térmico em àgua quente preferível devido à possibilidade de melhor con trole da temperatura. BENDA e RICAUD (1977) salientaram o fato de que a àgua possui grande capacidade de aquecimento por unidade de volume, sendo mais eficiente para a cura de doenças na termoterapia; além disso requer menor tempo para o tratamento, a temperatura é controlada mais facilmente durante o tratamento e em qualquer parte da unidade de tratamento, e o colmo atinge a temperatura especificada para o controle muito mais rapidamente.

STEINDL (1974b) admitiu que o tratamento com ar quente é usado extensivamente na Louisiana e menos em outros paises, com dificuldades de se controlar seguramente a tempera tura durante o processo, mas com germinação melhor que o trata mento com àgua quente quando se utiliza canas imaturas. 0 tratamento em àgua quente $\bar{e}$ usado na maioria dos paises onde não é necessārio tratar-se colmos imaturos ou muito novos.

Informações coletadas por MATSUOKA (1984c) reve laram que era na Louisiana-EUA, o único local do mundo onde se utilizava ainda o tratamento térmico a ar quente e tentava-se utilizar o vapor quente, porém que tais sistemas de termotera- 
pia foram abandonados pelas dificuldades operacionais e ineficiência que apresentavam. Em substituição está implantando-se - sistema tradicional de tratamento com água a $50,5^{\circ} \mathrm{C}$ por 2 ho ras. Devido a cana-de-açucar disponivel para tratamento ser muito jovem, é realizado o tratamento do colmo inteiro.

\section{- Controle do RSD por àgua quente}

Através dos trabalhos pioneiros de HUGHES e STEINDL (1955) na Austrālia, concluiu-se que uma combinação de tempo e temperatura da água curava a doença do RSD na varie dade Q28 sem afetar a brotação. Entretanto, al qumas variedades eram mais sensiveis à àgua quente que a $Q 28$ e quando o tratamento térmico começou a ser utilizado em escala comercial,adotou-se como padrão o tempo de 2 horas à temperatura de $50^{\circ} \mathrm{C}$.

STEINDL (1974b) admitiu vārias combinações de tempo e temperatura, usualmente entre 2 a 3 horas e 50 a $51^{\circ} \mathrm{C}$, sendo usada em diversos paises, com alto grau de controle do RSD e, dependendo do método de plantio, colmos inteiros ou em pedaços são submetidos aa tratamento.

Em pesquisas com tratamento térmico com àqua para o controle do RSD, ANTOINE (1957) observou que passaramse 13 minutos para a temperatura interna do tolete de cana-deaçúcar com 2,2 cm de diāmetro (variedade M134/32) atingir aque la do banho $\left(50^{\circ} \mathrm{C}\right)$. Para um tolete de $6,1 \mathrm{~cm}$ de diāmetro, 0 in 
tervalo foi de 75 minutos, e para a Ebene $1 / 37$, com $6,3 \mathrm{~cm}$ de diâmetro, o intervalo foi de 85 minutos.

FARRAR (1958) constatou que o RSD pode ser eliminado com temperatura de $49^{\circ} \mathrm{C}$ por 2 horas no interior do colmo ou, mantendo-se a temperatura de $50^{\circ} \mathrm{C}$ durante 1 hora.

Outro trabalho analisando as relacões tempo-tem peratura em colmos de cana-de-açūcar submetidos à termoterapia foi realizado por RICAUD (1968). Utilizando equipamento especí fico, foi medida a temperatura na parte central interna de toletes de apenas uma gema e toletes com 3 gemas com diferentes diâmetros, após iniciado o tratamento térmico,com os seguintes resultados:

\begin{tabular}{ccc}
\hline $\begin{array}{c}\text { Diâmetro } \\
(\mathrm{cm})\end{array}$ & $\begin{array}{c}\text { Toletes de } 1 \text { gema } \\
\text { (minutos) }\end{array}$ & $\begin{array}{c}\text { Toletes de } 3 \text { gemas } \\
\text { (minutos) }\end{array}$ \\
\hline 3,0 & 25 & 28 \\
3,9 & 40 & 43 \\
4,5 & 50 & 65 \\
\hline
\end{tabular}

observando-se a demora para que a temperatura fosse uniformizada em todas as partes do tolete, concluiu o autor, que o diāmetro do colmo é mais importante que seu comprimento, sendo a transmissão do calor governada pela menor distância do exterior ao centro do colmo, e que a casca da cana-de-açúcar tem menor poder de isolamento térmico que a medula. 
Com ess as observações caracterizou-se o comportamento da cana-de-acúcar submetida ao banho térmico. Com base nessas informações MATSUOKA (1975) concluiu que nas condições usuais de toletes de 2,5 a $3,5 \mathrm{~cm}$ de diāmetro, o tratamento de $50^{\circ} \mathrm{C}$ por 2 horas seria suficiente para se ter aquela temperatú ra no centro do colmo da cana-de-açúcar, pela mínimo de 1 hara requerida para a inativacão do agente causal. Uma vez que o comprimento do colmo não influencia a eficiência do tratamento (HUGHES e STEINDL, 1955 e RICAUD, 1968) e as relações de tempo/temperatura analisadas por ANTOINE (1957), FARRAR (1958) e RICAUD (1968) compreende-se a afirmação de BENDA (1977) de que o sistema de tratamento com àgua quente pode ser adaptado para aceitar colmos inteiros, toletes e gemas isoladas.

Trabalhos no sentido de averiguar a eficiencia do tratamento térmico em água nos padrões de tempo e temperatú ra indicados $\left(50^{\circ} \mathrm{C} / 2\right.$ horas) mostraram a exata situaça do controle do RSD atravēs desse método. CHU et alii (1960) testaram lotes de cana-de-açúcar com RSD em vārias combinações de tempo e temperatura e analisaram a infeccão residual através da ava liaça dos sintomas internos nas plantas cultivadas após os tratamentos. Os resultados a seguir apresentados pernitiram concluir que a cura do RSD não é conseguida totalmente. 


\begin{tabular}{|c|c|c|c|c|c|c|}
\hline${ }^{\circ} \mathrm{C}$ & Minutos & Nọ & toletes & tratados & $\%$ & infeccão \\
\hline 49 & 120 & & 223 & & & 10 \\
\hline 50 & 80 & & 115 & & & 5 \\
\hline 50 & 100 & & 115 & & & 8 \\
\hline 50 & 120 & & 165 & & & 1 \\
\hline 51 & 120 & & 217 & & & 2 \\
\hline 52 & 20 & & 218 & & & 30 \\
\hline Test & & & 120 & & & 100 \\
\hline
\end{tabular}

Trabalhos conduzidos por STEINER e BYTHER (1975) no Havai pela Hawaiian Sugar Planter's Association-HSPA mostraram os resultados da avaliaça da porcentagem de infeccão por RSD em colmos tratados termicamente em diferentes tempo/temperaturas, na forma de tratamento seriado.

\begin{tabular}{lcc}
\hline${ }^{\circ} \mathrm{C}$ & Minutos & $\%$ infecção do RSD \\
\hline Controle & & 100,0 \\
52 & 30 & 0,6 \\
52 & $30-30(2$ dias $)$ & 2,6 \\
52 & $30-30-30(3$ dias $)$ & 1,2 \\
52 & 45 & 0,4 \\
50 & 120 & 0,0 \\
\hline
\end{tabular}

Na Africa do Sul, a South African Sugar Associa tion - SASA (1979) avaliou a eficiēncia do tratamento térmico em àqua nos tempos de $1,5-2,0-2,5$ e 3,0 horas à temperatu- 
ra de $50^{\circ} \mathrm{C}$. Concluiu que menos de $1 \%$ das amostras tomadas após - tratamento apresentaram infeccão pela bactéria do RSD, avaliadas por microscopia de contraste de fase, quando se tratou a 2 horas ou mais. Porém, com o tratamento a 1,5 hora a $50^{\circ} \mathrm{C}$, a incidencia de RSD foi de $4,4 \%$ e as amostras de colmos não tratados apresentaram $94,4 \%$ de incidēncia de RSD.

CRUZ (1983) utilizando-se do processo de colora cão dos vasos funcionais do xilema de plantas sadias (tratadas termicamente) concluiu que a inativação do agente causal do RSD não era total, sobrando touceiras contaminadas provenientes de toletes submetidos à termoterapia a $50^{\circ} \mathrm{C}$ por 2 horas.

0 conhecimento dessa infecção residual não atin gida pelo tratamento térmico $\left(50^{\circ} \mathrm{C} / 2\right.$ horas) jä havia levado à indicação de que o retratamento térmico em sucessivos anos seria necessārio para o controle total do RSD (STEINDL, 1961 ). Este autor mencionou que devido ao fato, o tratamento térmico na Austrália foi estendido para 3 horas com cura mais completa do RSD, embora ocorra, mesmo assim, algum escape de toletes doentes. ABBOTT (1963) admitiu que em tratamento térmico em larga escala, a completa eliminação do agente causal é impossí vel e aproximadamente $5 \%$ de infeccão pode ocorrer em colmos d retamente tratados. Ambos os autores (STEINDL, 1961, ABBOTT, 1963 e STEINDL, 1974b) sugeriram programa continuo de retratamento térmico, usando a cada ano o material previamente tratado, ou que esteja relativamente livre da doenca, para que ela possa ser reduzida ao minimo. 
ANTOINE e RICAUD (1964) avaliaram os efeitos do aumento do tempo de 2 horas no tratamento a $50^{\circ} \mathrm{C}$ em āgua e cal cularam a seguinte redução na porcentagem de brotação em relação ao tratamento bäsico de $50^{\circ} \mathrm{C}$ por 2 horas:

$$
\begin{aligned}
& 50^{\circ} \mathrm{C} / 2 \text { horas }-100 \% \\
& 50^{\circ} \mathrm{C} / 2 \text { horas }+15 \text { minutos - menos } 54 \% \\
& 50^{\circ} \mathrm{C} / 2 \text { horas }+30 \text { minutos - menos } 50 \% \\
& 50^{\circ} \mathrm{C} / 2 \text { horas }+45 \text { minutos - menos } 72 \% \\
& 50^{\circ} \mathrm{C} / 2 \text { horas }+60 \text { minutos - menos } 79 \%
\end{aligned}
$$

LOPEZ-ROSA e ADSUAR (1970) em Porto Rico, atra-

vēs de avaliações de sintomas internos, concluiram que o trata mento térmico em āgua a $50^{\circ} \mathrm{C}$ por 3 horas não eliminou o agente causal do RSD. A mesma conclusão chegou MATSUOKA (1971a) no Brasil, após analisar plantas oriundas de viveiros tratados. termicamente, através de diagnose em plantas de capim elefante (P. purpureum), usados como indicadoras da presenca de infecção por RSD (MATSUOKA, 1972).

Em trabalho pioneiro para avaliar a eficiência comparativa do tratamento. térmico a $50,5^{\circ} \mathrm{C}$ por 2 horas e por 3 horas e pesquisar a longevidade do efeito do tratamento térmi,co, MATSUOKA (1984b) chegou às conclusões que não houve aumen to de eficiencia de controle estendendo-se o tempo de tratamen to para 3 horas e, que a reinfeccão que ocorre a partir da infeccão residual não controlada pelo tratamento térmico é tal que, após cinco multiplicacões sucessivas, as plantas podem apresentar-se tão contaminadas quanto uma planta de cana-de- 
açūcar não tratada.

- Equipamentos de termoterapia atravēs de àgua

Grande número de espécies de plantas cultivadas, na forma de sementes, mudas, bulbos, caules, brotos e plantas inteiras tem sido tratadas termicamente para solucionar diversos problemas, e sobrevivem plantas livres de algumas bactērias, micoplasmas, vîrus, nematōides e insétos (BENDA, 1972 ).

Apōs o sucesso obtido com o tratamento térmico em à qua quente para controle da estria clorótica em cana-deaçūcar, por volta de 1923/32 (SINGH, 1967 e BENDA, 1972) numerosas doencas tem sido controladas pelo calor, incluindo carvão, mosaico, escaldadura das folhas e RSD (BENDA e RICAUD, $1978)$.

Especificamente para o controle do RSD o trata mento em àgua quente foi inicialmente realizado em tanques de metal, com tamanhos variados, atē aproximadamente $10 \mathrm{mil} 1 \mathrm{i}$ tros de capacidade, sendo a àgua aquecida por vapores de caldeira (STEINDL, 1961). Outras fontes de energia podem ser utilizadas como energia elétrica (BRIEGER, 1967) ou óleo diesel (DODSON, 1973).

MATSUOKA (1975) considerou como críticos no tra tamento com ägua quente, o controle adequado da temperatura, proporcão adequada em volume de àqua e de colmos e, estágio de 
maturação da cana-de-açūcar. A temperatura é importante pois a combinacão tempo/temperatura requerida para o controle do RSD é critica para a brotação do colmo tratado (ANTOINE e RICAUD, 1964) e tambēm para a inativação do agente causal do RSD (CHU, 1960; MATSUOKA, 1971a; STEINER E BYTHER, 1975; SASA, 1979).

A movimentação da àqua quente è feita através de bombas com capacidade suficiente para circular toda a água do tanque ao menos 6 vezes por hora (STEINDL, 1961). A proporcão de volume de àgua e volume de colmos e consequente movimen tação da água pelo material e ser tratado é fator de eficiēncia para os equipamentos de termoterapia através de água. HUGHES e STEINDL (1955), aconselharam a proporção de 1 volume de colmos para 6 a 7 volumes de àgua, variando para mais conforme a maior potenncia do sistema de aquecimento/circulação da àqua.

KING e THOMSON (1972) avaliando diversos tanques de tratamento tērmico em ägua na Äfrica do Sul consideraram como importantes num equipamento a manutenção da temperatu ra próxima dos $50,5^{\circ} \mathrm{C}$ pelas 2 horas, adequados sistemas de aquecimento, circulação da àgua e controle de temperatura. Acrescentaram que 0 isolamento efetivo do tanque contra perdas de calor e proteção da corrosão são fatores importantes para a operação econômica de qualquer modelo. Admitiram que a simplicidade operacional e registros visuais de temperatura precisos são importantes num projeto de equipamento de tratamento térmi co. 
A utilização de tanques de tratamento térmico em àgua nos paises canavieiros, e principalmente no Brasil, só foi possivel com a construção particular de equipamentos que reproduzissem os padrões básicos requeridos para a inativação do agente causal do RSD. Desse modo muitas estações experimentais de cana-de-açucar e algumas empresas canavieiras construi ram seus próprios equipamentos com os recursos então disponīveis (BRIEGER, 1967; DODSON, 1973). As dificuldades para construir-se um bom equipamento são evidentes e com isso a termote rapia era usada em pequena escal a no Brasil.

Atentos ao problema, surgiu no início da década de 1970 o equipamento de tratamento térmico projetado por SILVA (1974). Tal equipamento caracterizou o sistema de tratamento térmico de gemas isoladas e objetivava solucionar o problema da inexistencia de aparelho adequado para a operação; foi projetado para resolver os problemas provacados pelo diámetro variável numa mesma variedade, condução pobre do calor atravēs da casca do colmo e problemas na circulaça adequada de àgua. O sistema é operacionalizado através de vārias etapas de traba Tho: corte do colmo, seccionamento em pedaços de $3-5$ gemas, sec cionamento dos colmos ao meio, extração das gemas, preparo das gemas para receber o tratamento térmico, tratamento propriamen te dito, tratamento químico convencional, prë-brotação em canteiros e transplantio das mudas em raiz nua para o campo. Este sistema de tratamento tērmico està sendo largamente utilizado no Brasil, principalmente no Estado de São Paulo. Com o traba- 
Tho de SILVA (1974) o Brasil passou a ter disponivel um equipa mento de tratamento térmico para controle do RSD com fabricacão seriada.

Posteriormente TOKESHI et alii (1983) desenvolveram outro equipamento para controle do RSD, baseado no siste ma de tratamento térmico de toletes de 3 gemas, sistema tradicional ainda utilizado pelos tanques antigos de fabricacão par ticular (também tratavam o colmo inteiro) ou por tentativas mais recentes de contruir-se equipamentos no sistema convencio nal (colmos inteiros ou toletes), com controles mais confiáveis de temperatura durante o tratamento. O sistema de tratamento térmico em toletes de 3 gemas então desenvolvido permitiu, com recursos eletrônicos modernos, correta manutenção da temperatura de tratamento (MATSUOKA, 1984a). A embalagem dos toletes de 3 gemas em recipientés de malha plástica (sacos de batata) permite intimo contato água-colmo e facilita sua circu 1ação. A caracteristica operacional do sistema, com entradasaida intermitente de colmos no tanque, em unidades de 3 sacos de toletes por vez, espacadas a cada 24 minutos, permite opera cão ininterrupta do aparelho e alto grau de controle de temperatura. As operações necessārias para a realização do tratamen to térmico em toletes de 3 gemas restringem-se ao seccionamento dos colmos em toletes e posterior ensacamento, tratamento térmico, químico e volta ao campo para plantio, sendo todas as atividades de campo realizadas na forma convencional de plantio de cana-de-açūcar comercial. 
Atualmente, os sistemas de tratamento térmico em toletes de 3 gemas e em gemas isoladas estão em utilização no Brasil. Embora existam caracteristicas totalmente diferentes entre os sistemas, notadamente em relacão aos custos fixos e variáveis necessários, ao produtor interessa a questão funda mental: qual sistema é mais eficiente e qual é o mais eficaz para o controle do RSD.

2.4. Diagnose do RSD

A dificuldade existente na diagnose do RSD tem se constituido num dos mais sērios entraves à realização de pesquisas relacionadas com a doenca (MATSUOKA, 1972).

A partir da definicão na Austrālia que o : RSD era doença transmissível, atravēs da determinação dos sérios problemas de crescimento que plantas da variedade Q28 apresentavam quando submetidas à inoculação com extratos de plantas doentes, observou-se que colmos com RSD apresentavam descolora cão alaranjada-avermelhada dos feixes vasculares na altura dos nōs. Em brotos jovens os sintomas apresentavam-se como descolo ração rósea na região apical.

Os sintomas internos descritos por STEINDL (1961) foram amplamente aceitos embora seu valor como diagnóstico fosse considerado insatisfatōrio, devido a variacões observadas entre variedades e tambēm conforme as condições climá ticas e fisiológicas (RICAUD, 1974).

As dificuldades de deteção de infecção pelo 
RSD através do único sintoma descoberto foram rapidamente sen do avaliados. THOMSON (1958) considerou a avaliacão pela sinto matologia interna muito problemātica. RICAUD (1974) citou outras doenças que podem causar descoloração vascular: Fusarium, Podridão Vermelha, Escaldadura das folhas, Podridão da Casca, etc. TOKESHI (1980) admitiu que a ausēncia de sintomas internos não indicava sanidade do material, e a descoloração vascular na região nodal seria o resultado da reacão da planta a or ganismos estranhas, não sendo especifica para o agente causal do RSD. MUNIYAPPA e SETTY (1982) em estudos de avaliação da reaça de variedades ao RSD concluiram que a bactéria causadora do RSD e sintomas na região nodal nem sempre estão associados.

Desde que os sintomas diagnōsticos nas plantas doentes de diversas variedades sob diferentes condições apresentavam-se tão inconsistentes, métodos de diagnose atravēs de plantas indicadoras foram avaliados. Inicialmente a prōpria ca na-de-açúcar, com variedades que mais facilmente mostravam sin tomas em tecidos jovens foram testadas. SCHEXNAYDER (1960) apon tou a variedade CP36-105 e GILLASPIE et alii (1966) relataram que a CP44-101 também era eficiente como indicadora. SINGH (1969) por sua vez admitia bons resultados para a Co421.TEAKLE et alii (1978b) consideraram a Q28 como opcão entre as varieda des indicadoras. Entretanto, a demora ( 4 a 12 semanas). entre inocular-se o caldo de colmos suspeitos num que mostre sintomas mais evidentes e formação dos sintomas diagnósticos, tor- 
navam esta técnica insatisfatōria.

MATSUOKA (1972) estudando diversas gramineas hospedeiras do agente causal do RSD concluiu que o capim efefante ( $P$. purpureum) é a planta mais apropriada para uso como indicadora. STEINDL (1974a) considerou que o "bana grass", hibrido de $P$. purpureum e $P$. americanum, mostrou excelentes resultados após inoculado com caldo de variedades a serem observadas.

Apesar dos resultados obtidos, o uso de plantas indicadoras, seja a prōpria cana-de-açūcar ou outras espécies não obtiveram pleno sucesso. BECHET (1976) citou os resultados inconsistentes obtidos com a variedade CP44-101 e P. purpureum na Äfrica do Sul. SASA (1976) admitiu que os resultados com "bana grass" tambēm foram insatisfatōrios. SuDo (1980) concluiu que o $P$. purpureum reage inespecificamente para os agentes causais de diversas doencas vasculares da cana-de-acucar.

Sobre as tentativas feitas por diversos pesquisadores, para o desenvolvimento de teste quimico para precisar melhor o diagnóstico do RSD, RICAUD (1974) analisou que houve sucesso apenas parcial em certos casos, e nenhum teste estudado encontrava aplicacão rotineira. 0 autor referia-se às tenta tivas de FARRAR (1957) com coloração de tecidos sadios e doentes tratados com perōxido de hidrogēnio e àcido clorídrico, de ANTOINE (1960) com o teste histoquimico envolvendo a reducão do $2,3,5$ - cloreto trifenil tetrazóleo também para coloracão diferencial de tecidos sadios e com RSD, e também os trabalhos 
de ROTH e WHITEHEAD (1965) com nitrato de prata e amōnia ou hidrōxido de potássio, que coloriam de vermelho os feixes fibro-vasculares de colmos com RSD:

Técnicas de deteção serolōgica foram tentadas para avaliar a presenca do RSD. Trabalhos de GILLASPIE (1971) com antisoro não obteve resultado. DAMANN et aliz (1978) propu seram a técnica de serologia específica e microscopia eletrōni ca como sendo mais sensivel que a microscopia eletrónica com imersão rāpida. HARRIS e GILLASPIE (1978) sugeriram a técnica indireta de anticorpos fluorescentes como sendo mais sensivel que a microscopia de contraste de fase e que poderia ser usada rotineiramente. As tentativas de testes serológicos, entretanto, talvez devido ao seu custo, não tiveram adoção extensiva, restringindo-se a trabalhos experimentais.

\section{- Diagnose por microscopia de contraste de fase}

GILLASPIE et alii (1973) indicaram a microscopia de contraste de fase ou campo escuro como possivel de ser utilizada para a diagnose da bactēria do RSD, diretamente em exudados do xilema de plantas doentes. STEINDL (1976) admitiu que a microscopia de contraste de fase proporcionava satisfatō ria identificacão do RSD, sendo semelhante em precisão ao teste com "bana grass" e microscopia eletrōnica.

$$
\text { GILLASPIE et alii (1976) concluiram que a mi- }
$$
croscopia de contraste de fase tinha potencial e deveria ser 
aproveitada como método de avaliação para resistência ao RSD, uma vez que constataram que clones resistentes a danos por RSD contēm menos bactērias que clones suscetiveis.

BAILEY (1981) orientou a amostragem de campo pa ra a rápida diagnose do RSD pela microscopia de contraste de fase e sua utilizacão pelos produtores na Africa do Sul. SANGUINO et alii (1984) orientaram o uso da microscopia de contraste de fase para diagnóstico do RSD em amostras de 50 colmos por hectare coletados de touceiras causalizadas. A análise da presença das bactérias do RSD seria quantitativa, segundo a sequinte graduação:

$$
\begin{array}{ll}
\text { (-) nenhum talo bacteriano } & \text { - sem infeccão } \\
\text { (+) } 1-5 \text { talos } & \text { - infeccão baixa } \\
(++) 5-10 \text { talos } & \text { - infeccão moderada } \\
(+++) \text { mais de } 10 \text { talos } & \text { - infecção alta }
\end{array}
$$

Os mesmos autores consideraram ser satisfatório o campo que apresentar ate $5 \%$ dos colmos amostrados com infeccão baixa,sem entretanto, apresentar nenhum colmo com infecão moderada ou alta. BAILEY e FOX (1985) relataram o uso da microscopia de contraste de fase na Africa do Sul desde 1977 testando diver sas formas de amostragem de campo para o melhor diagnóstico prático da infeccão por RSD. Concluiram que amostras de 10 a 100 colmos por campo a ser analisado, coletados ao acaso, apre sentavam bons resultados quando o campo estivesse severamente infectado por. RSD. Em campos com baixa infeccăo a coleta de colmos foi orientada para os colmos mais finos das touceiras 
mais fracas, analisando-se tão somente a presença ou auséncia de bactērias causadoras do RSD.

\section{- Diagnose por fluxometria}

As observações de TEAKLE et alii (1975) avalian do o fluxo de àgua através de tolete de cana-de-açūcar com um nō, cuja vazão foi de 13 a $19,6 \mathrm{~m} 1 / \mathrm{minuto}$ para 6 clones suscetíveis, 2,6 a $8,4 \mathrm{ml} / \mathrm{minuto}$ para 3 clones tolerantes, e 1,4 $\mathrm{ml} / \mathrm{minuto}$ para a variedade H60-6909 considerada imune ao RSD, conduziram à conclusão de que esta correlaça positiva entre resistência ao RSD e resistência ao movimento de àgua poderia indicar que a anatomia vascular estivesse envolvida no processo. Outra evidencia foi demonstrada com a coloracão dos vasos. por onde o fluxo se realizava, com tinta nanquim, demonstrando-se que o número médio de feixes vasculares que conduziram o corante atravēs do tolete de um nō, foi maior em 2 clones suscetiveis ao RSD do que em 3 clones tolerantes e no clone imune $\bar{a}$ doença.

VALARINI (1978) adaptando a metodologia emprega da por TEAKLE et alii (1975) dimensionou equipamento que permi tiu avaliar através da fluxometria, algumas relacões da resistência ao RSD em cana-de-açūcar. As seguintes conclusões foram apresentadas: há correlação entre a diferença de vazão em colmos sadios e doentes e o grau de suscetibilidade ao RSD; a va$z$ ão é diretamente proporcional ao número de vasos funcionais 
do colmo; é possível avaliar a resistência das variedades de cana-de-açúcar, pela determinação da vazão de àgua através do colmo. Entre as variedades utilizadas no trabalho, a NA56-79, a mais plantada no Brasil com aproximadamente 2 milhões de hec tares, foi considerada suscetivel ao RSD.

Tornando a pesquisar características da anatomia vascular da cana-de-acūcar e suas relações com a resistência ao RSD, TEAKLE et alii (1978a) constataram que variedades consideradas resistentes ao RSD, com baixa vazão de āqua nos colmos, apresentavam maior número de ramificações dos vasos de metaxilema nos nōs, quando comparadas com variedades suscetiveis.

DOUGLAS (1981) admitiu que a anatomia vascular não é suficiente para explicar o grau de suscetibilidade entre variedades. A correlação positiva entre diferenças de vazão en tre colmos sadios e doentes e a suscetibilidade de variedades de cana ao RSD, jā descrita por VALARINI (1978), foi confirmada, assim como a avaliaça de suscetiveis ao RSD para as varie dades NA56-79 e CB41-76. Assegurou o autor, que o método de fluxometria é simples, seguro, barato e rápido, para separar variedades resistentes e suscetiveis ao RSD.

CRUZ (1983) noutro trabalho utilizando o método da fluxometria para avaliacão do RSD e a interferéncia da escaldadura das folhas nas medicões, confirmou as conclusões de VALARINI (1978) e DOUGLAS (1981) quanto à correlação positiva entre vazão de àqua entre colmos sadios e com RSD e a possibi- 
lidade de avaliar-se, através desse processo, a resistēncia ao RSD. Este método; entretanto, não funcionou para avaliacão de resistência à escaldadura das folhas, que provavelmente pode interferir nas medidas de vazão realizadas para anālise da resistência ao RSD, provocando aumento de vazão no xilema. Segun do o autor, a influéncia da escaldadura das folhas no processo, define mecanismo diferente de patogenicidade da sua bactéria em relação ao agente causal do RSD, provavelmente devido à desintegraça das paredes celulares do xilema e tecido parenquimatoso adjacente.

CHAGAS (1985) avaliando a relação entre o nūmero de vasos funcionais do xilema coloridos pela corrente trans piratória, comparando colmos sadios e com RSD, concluiu ser es te método eficiente para quantificar a contaminacão pela doen-ca. Indicou também, que a utilização dessa técnica, permitiu identificar lotes de colmos doentes, mesmo com baixos niveis de contaminação. 


\section{MATERIAL E METODOS}

3.1. Sistemas de tratamento tērmico

Foram utilizados para avaliação os sistemas de tratamento térmico de gemas isoladas descrito por SILVA (1974) e de tratamento por toletes de 3 gemas desenvolvido por T0KESHI et alii (1983).

Para o tratamento tërmico de gemas isoladas foram adotadas as operações padrões do sistema, ou seja: corte dos colmos no campo, transporte para o galpão de manuseio, se $\underline{c}$ cionamento transversal dos colmos em toletes de $3-5$ gemas e longitudinal caso os colmos fossem demasiadamente grossos, extracão das gemas em aparelho próprio conjugado ao sistema, seleção das gemas sem danificações mecānicas, colocação das ge- 
Pelo fato dos equipamentos possuirem sistemas de controle de temperatura diferentes (sensores termoeletrónicos para o equipamento de toletes e termómetros de mercūrio pa ra o de gemas isoladas), foi realizada calibracão igual para ambos. Para isso utilizou-se o termómetro do equipamento de ge mas isoladas para calibração dos sensores do equipamento de tratamento de toletes.

3.2. Variedades empregadas e obtenção das mudas tratadas

Para a conducão do experimento, foram escolnidas variedades de cana-de-açúcar com reconhecida suscetibilida de ao RSD.

Foram colhidas, para tratamento térmico, colmos provenientes de plantações de 3 variedades com os mais altos graus de infecção encontrados: 1 - colmos da variedade CB41-76 cujas plantas tinham sido sucessivamente multiplicadas sem qualquer controle desde o ano de 1972, quando foram inoculados com RSD; 2 - colmos da variedade NA56-79 originärios de touce ras inoculadas com RSD em 1979;3- colmos da variedade CB49-260 retirados de talhões comerciais de 60 corte da Fazenda Montevideo em Araras-SP.

Todas as variedades foram tratadas termicamente nos dois equipamentos citados, conforme a sistemática operacio nal de cada um, em setembro de 1982, e instalado com este mate rial o viveiro de produção de mudas para o ensaio de campo pro 
priamente dito. No sistema de gemas isoladas optou-se por realizar o transplantio para o campo com as mudas enraizadas em copos plásticos, a partir da brotação após o tratamento térmico. Multiplicaram-se, evidentemente, lotes das variedades sem a realização do tratamento térmico.

\subsection{Ensaio de campo}

\subsubsection{Delineamento experimental}

Foi planejado o delineamento estatistico de blocos casualizados no esquema fatorial, composto de 6 blocos, 3 variedades (NA56-79, CB41-76 e CB49-260) e 3 tratamentos: RSD (colmos doentes), TTT (tratamènto térmico no sistema de to letes de 3 gemas) e TTG (tratamento tërmico no sistema de gemas isoladas). As parcelas experimentais tinham 5 sulcos de $10 \mathrm{~m}$ de comprimento, espacados de 1,40 metros, totalizando 70 metros quadrados de ärea ūtil.

\subsubsection{Instalação e condução do ensaio no campo}

0 ensaio foi conduzido na Estação Experimental de Cana-de-Açucar do IAA/PLANALSUCAR -em Araras-SP, em solo Latossol Vermelho Escuro-textura muito argilosa. 0 plantio com mudas de 11,5 meses de idade, previamente produzidas e 
preparadas para esse trabalho, foi realizado em 31 de outubro de 1983 em sulcação convencional para a cana-de-acūcar (25 a $30 \mathrm{~cm}$ ), adubados com $500 \mathrm{~kg} / \mathrm{ha}$ da fórmula 5-25-25. As mudas foram seccionadas em toletes de 3 gemas, atravēs de facões desin fetados em solucão de creolina a $20 \%$, e distribuidas na quanti dade de 5 toietes por metro linear de sulco ou 15 gemas/ metro de sulco, e cobertas com 3 a $5 \mathrm{~cm}$ de terra. Apōs o plantio, foi aplicado o herbicida Perflan na dosagem de 1,3 kg/ha, para con trole das plantas daninhas, evitando-se a concorréncia do mato at $\bar{e}$ o fechamento das entrelinhas da cultura.

\subsubsection{Parâmetros agrícolas analisados.}

os parāmetros agrícolas foram anal isados

em

dois cortes consecutivos (cana planta e primeira soca), cujos cortes foram realizados em dezembro de 1984 e dezembro de 1985 , respectivamente (cicio de cana de ano).

- Produtividade agricola (toneladas por hectare):

esse parámetro foi avaliado pela pesagem individual das parceIas com auxilio do dinamómetro marca CHATILLON, acoplado em car regadeira de cana-de-açucar, sendo pesados grupos de 100 colmos por vez. A projeção da média conseguida nos 6 blocos deter minou o indice de produtividade por hectare.

- Número de colmos industrializāveis: obtido a partir da contagem dos colmos à época da colheita; da média ob tida dos 6 blocos projetou-se o numero de colmos industrializă veis por hectare. 
- Altura média dos colmos e diāmetro na base,meio e ponta dos colmos: para a avaliação desses parāmetros tomouse 20 colmos por parcela experimental, coletados sequencialmen te no segundo sulco dos 5 existentes em cada parcela. A altura média foi calculada a partir de medicões feitas da base do col mo atē a ūitima folha do colmo que apresentava a região auricu lar visivel (folha +1 ). O diâmetro da base foi medido no $20 / 30$ entrenó a partir do solo, e o diàmetro da ponta a 2-3 entrenós abaixo da folha +1 , utilizando-se de paquímetro para as medicões realizadas.

- Peso médio por colmo: calculado a partir da pesagem das parcelas experimentais e da contagem do número de colmos industrializáveis encontrados em cada parcela.

\subsubsection{Anälises estatisticas}

0 processamento estatistico dos dados coletados foi realizado pelo Núcleo Regional de Economia, Estatistica e Informātica do IAA/PLANALSUCAR em Araras-SP. Foi aplicado o teste $F$ para a anālise de variancia e comparação de médias pela avaliação atravēs do teste de Tukey.

3.4. Avaliação da eficiēncia dos sistemas

3.4.1. Fluxometria de ägua atravēs dos colmos

Para as avaliações de fluxo de àgua atravēs dos 
colmos, foi utilizado o fluxōmetro desenvolvido por. VALARINI $(1978)$.

Aplicou-se a pressão de vãcuo $(30 \mathrm{~mm} \mathrm{de} \mathrm{Hg})$ e tempo de leitura (15 minutos) recomendados para as medicões, realizadas no 30 ou 40 nó dos colmos a partir do solo, em secões de $8 \mathrm{~cm}$ de nō mais parte de entrenōs.

Foram realizadas 180 determinações de vazão por variedade em cada tratamento testado, totalizando 1.620 determi nações na avaliação global do ensaio. Os colmos paraverificacão do fluxo foram coletados nas parcelas do ensaio de campo, sendo retirados 30 colmos por parcela, ou seja, 180 colmos nos 6 blocos. A coleta dos colmos foi feita em diferentes touceiras, ao acaso, evitando-se apenas os colmos com perfurações da broca da cana-de-açūcar. Todo colmo amostrado e submetido $\ddot{a}$ avaliação do fluxo de àgua, foi tambēm examinado quanto à presença de sintomas internos característicos do RSD.

os resultados das avaliações do fluxo de àgua atravēs dos colmos foram analisados estatisticamente segundo o esquema de blocos casualizados, considerando-se 60 blocos e 3 tratamentos (RSD, TTT e TTG). Cada bloco constou de 3 determi, nacões simultāneas de fluxo por tratamento ocupando, portanto, 9 posições das 10 disponíveis no fluxömetro.

3.4.2. Avaliação dos sintomas vasculares do RSD

As leituras para determinação da ocorrēncia de 
sintomas internos de RSD foram realizadas nos mesmos colmos utilizados para medicão do fluxo de água, após a retirada do material necessärio à fluxometria. Dessa forma foram observados 30 colmos por parcela e 180 colmos por variedade em cada tratamento, buscando-se os sintomas caracteristicos do RSD nos nós mais velhos do colmo. Admitiu-se a graduação dos sintomas em ausentes ( $A u)$, Fracos $(F r)$, Mēdios (Me) e Fortes (Fo), conforme a intensidade de ocorrēncia nos colmos observados.

3.4.3. Contagem de bactērias (Clavibacter xyli subsp. $x y(i)$ através de microscopia de contraste de fa se

A contagem de bactérias foi realizada atravēs da microscopia de contraste de fase, conforme as indicacoóes de GILLASPIE et alii (1973 e 1976), STEINDL (1976) e BAILEY (1976).

A extracão do conteúdo vascular (seiva) do 40 ou 5 ọ nó e entrenó a partir do solo, foi feita atravēs de centrifugacão a 3.000 rpm por um (1) minuto), procedimento utilizado por DAMANN (1981), apenas reduzindo-se o tempo de centrifugacão. Do extrato assim obtido, apōs homogeneização, foi to mado uma gota com auxilio de micro-pipeta, lançada em lâmina e coberta com laminula.

As contagens de bactērias foram feitas em um 
campo por amostra (colmo), na posição central da lamínula, em microscōpio LEITZ com equipamento de contraste de fase. As le turas foram padronizadas em aumentos de $1250 x$ com imersão e realizadas, após domínio da técnica visual, em aumento de $500 x$ sem imersão, obtendo-se, assim mais rapidez nas leituras e maior campo microscópico de observação.

Foram realizadas 18 leituras por variedade testada em cada tratamento aplicado, suficiente para amostragem dos lotes a serem observados, conforme deduções de BAILEY e FoX (1985), sendo, portanto, praticadas 162 tomadas de avaliacão de número de bactērias no total do trabalho. Nos colmos amostrados foram tambëm observadas a presença de sintomas internos de RSD e avaliada a vazão de àgua conforme o procedimen to descrito em 3.4 .

As leituras foram ordenadas conforme o grau de infecção de RSD encoritrado, ou número de bactérias contadas, sequndo a classificação proposta por SANGUINo et alii (1984).

\subsection{Apēndice}

Em apêndice são apresentadas as anālises de variancia por parcela experimental, para os parāmetros produti vidade agrícola, diâmetro médio dos colmos, altura média dos colmos, número de colmos industrializāveis por hectare e flú xo de āgua atravēs dos colmos. Também são relacionados os dados originais por parcela para os diversos parâmetros observa dos nas variedades estudadas e a precipitaça pluviométrica 
ocorrida nos anos de 1983, 1984 e 1985 e a média normal de pre cipitação para Araras, calculada em 30 anos de observação de dados. 


\section{RESULTADOS E DISCUSSAOO}

4.1. Avaliação dos paràmetros agrícolas

4.1.1. Producão de colmos por parcela

A aplicação do teste F (apēndice 1) definiu a existência de diferenças significativas entre variedades e entre tratamentos, ao nivel de $1 \%$ de probabilidade tanto para ca na planta como para a la soca. A interação variedades com tratamentos apresentou-se significativa apenas na cana soca, demonstrando haver diferenca de comportamento das variedades em relação aos tratamentos.

A tabela 1 apresenta as médias dos pesos obtidos para os tratamentos nas parcelas experimentais e a quanti- 
Tabela 1. Produção de colmos em toneladas por hectare (t/ha) e peso médio das parcelas experimentais $(\mathrm{kg})$ em cana planta e soca de 3 variedades, com 3 tratamentos cada .

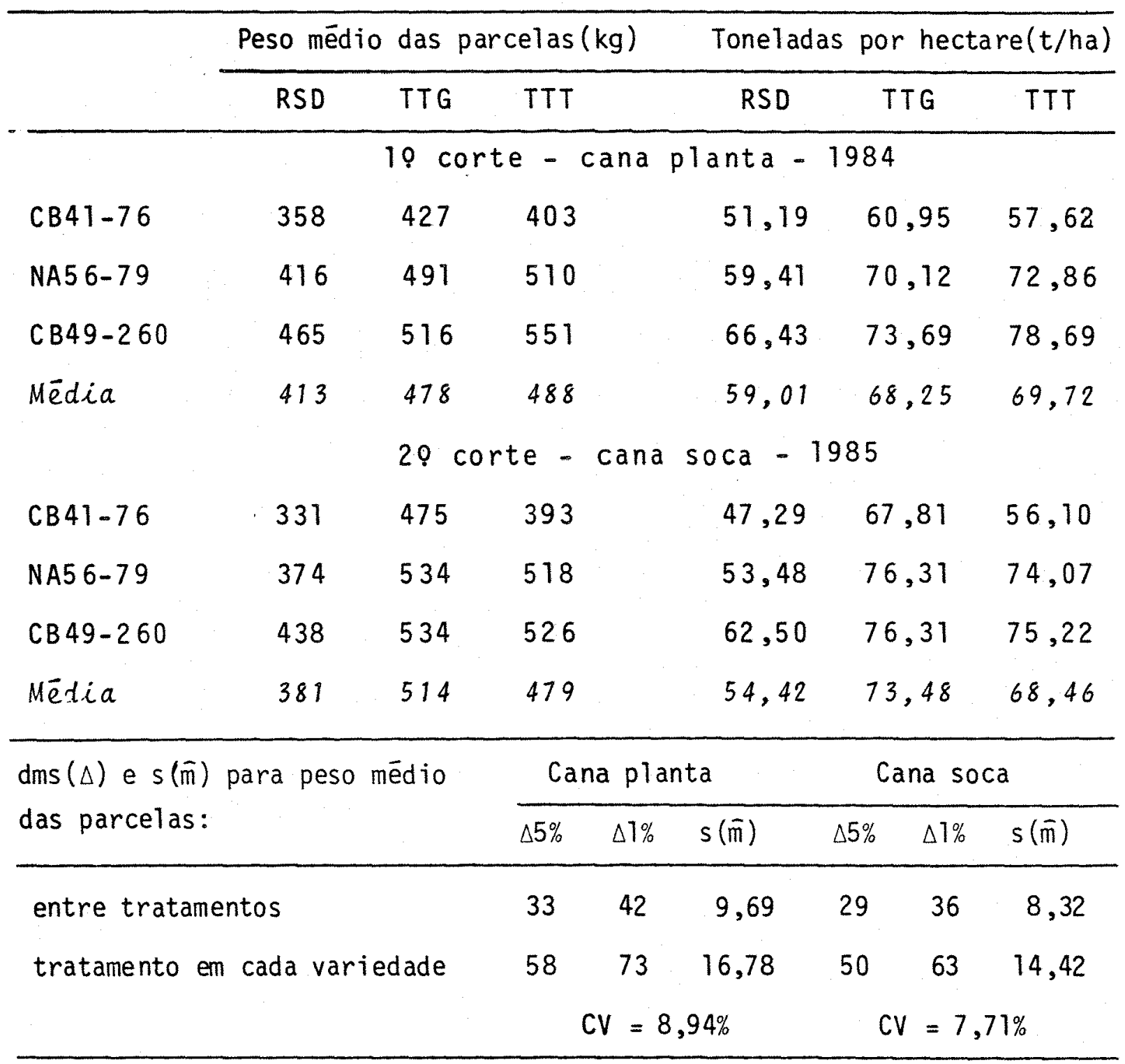

RSD - Raquitismo da soqueira

TTG - Tratamento tērmico de gemas isoladas

TTT - Tratamento tērmico de toletes de trés gemas. 
ficação da produtividade agrícola ( $t / h a$ ) tanto para cana planta como para primeira soca.

A confrontaça estatística mostrou, tanto em cana planta como em la soca que independente de variedades,os pe sos médios das parcelas dos tratamentos TTT e TTG foram semelhan tes, e ambos diferiram significativamente do tratamento RSD (canas doentes).

Embora o teste $F$ não tenha acusado, quando apli cou-se oteste de comparacões mūltiplas (Tukey) observou-se a nivel de variedades, em cana planta, que os tratamentos TTT e TTG também não diferiram estatisticamente. Os tratamentos térmicos (TTT e TTG) diferiram do tratamento RSD (canas doentes) na variedade NA56-79; para a CB41-76 o tratamento TTT não dife riu do RSD e na CB49-260, o tratamento TTG não diferiu do RSD, porém em ambos os casos, notou-se a tendēncia nîtida de vantagens para os tratamentos TTT e TTG em relação ao RSD.

Em cana soca, para as variedades NA56-79

e

CB49-260 houve igualdade estatistica entre os tratamentos TTT e TTG, com ambos diferindo do tratamento RSD. Para a CB41-76, os trēs tratamentos diferiram entre si, porém com tendéncia de maiores médias para os sistemas de tratamento térmico empre gados, em relacão à testemunha não tratada (RSD).

Desde que não evidenciou-se diferenças estatisticas significativas entre os dois métodos de tratamentos térmicos (TTG e TTT), pode-se avaliar a reacão das plantas tratadas termicamente em relacão àquelas não tratadas e definir,des 
ta forma, o efeito da doença do RSD na cultura da cana-de-açucar. Assim demonstraram-se acréscimos de produtividade agrícola (t/ha) da ordem de $16 \%, 20 \%$ e $15 \%$ para as variedades CB41-76, NA56-79 e CB49-260, respectivamente; em cana planta. Na soca, os ganhos de produtividade agricola foram da ordem de $37 \%$, $41 \%$ e $21 \%$, respectivamente, para as variedades CB41-76, NA56-79 e CB49-260.

As perdas de produtividade admitidas ao RSD estão coerentes com estudos efetuados por diversos autores, em diversos paises canavieiros (STEINDL 1961, HUGHES, 1974, MATSUO KA 1974 e 1984). Os trabalhos de MATSUOKA (1984), realizados no Estado de São Paulo, mostraram na variedade CB41-76, perdas de $14 \%$ em cana planta e $25 \%$ em soca. Na variedade CB49-260, as perdas foram de $17 \%$ e $21 \%$, respectivamente para cana planta e soca. A comparação destes dados define a situação fitossanitāria das variedades antes da realização dos tratamentos térmicos, e renova a importāncia econōmica do RSD, quando define-se as perdas provocadas pela doenca na variedade NA56-79, a mais plantada no Brasil, como sendo da significativa ordem de $20 \%$ e $41 \%$ em planta e soca, respectivamente, comparando-se plantas severamente contaminadas pelo RSD com plantas da mesma origem, porém, tratadas termicamente.

4.1.2. Diâmetro médio dos colmos (mm)

A anālise de variāncia (apēndice 2) foi feita 
Tabela 2. Diâmetro médio entre medidas na base, meio e ponta dos colmos, em cana planta e soca de 3 variedades,com 3 tratamentos cada.

\begin{tabular}{lccc}
\hline & \multicolumn{3}{c}{ Diâmetro médio dos colmos $(\mathrm{mm})$} \\
\cline { 2 - 4 } & RSD & TTG & TTT \\
\hline 10 & corte - cana planta & \\
\hline CB41-76 & 24,30 & 25,62 & 24,31 \\
NA56-79 & 24,69 & 25,10 & 24,84 \\
CB49-260 & 23,38 & 25,06 & 24,23 \\
Média & 24,12 & 25,26 & 24,46 \\
\hline CB41-76 & 23,43 & 24,67 & 24,27 \\
NA56-79 & 22,88 & 24,08 & 23,93 \\
CB49-260 & 22,40 & 23,57 & 23,63 \\
Média & 22,91 & 24,17 & 23,94 \\
\hline
\end{tabular}

$\operatorname{dms}(\Delta)$ e $s(\bar{m})$ para diâmetro médio

\begin{tabular}{llllll}
\multicolumn{2}{c}{ Cana planta } & \multicolumn{3}{c}{ Cana soca } \\
\hline$\Delta 5 \%$ & $\Delta 1 \%$ & $\mathrm{~s}(\overline{\mathrm{m}})$ & $\Delta 5 \%$ & $\Delta 1 \%$ & $\mathrm{~s}(\overline{\mathrm{m}})$
\end{tabular}

entre tratamentos

$\begin{array}{llllll}0,83 & 1,05 & 0,2409 & 0,63 & 0,80 & 0,1822\end{array}$

tratamento em cada variedade

$\begin{array}{llllll}1,44 & 1,82 & 0,4173 & 1,09 & 1,38 & 0,3157\end{array}$

$\mathrm{CV}=4,15 \% \quad \mathrm{CV}=3,27 \%$

RSD - Raquitismo da soqueira

TTG - Tratamento térmico de gemas isoladas.

TTT - Tratamento térmico de toletes de trēs gemas. 
com os dados médios dos diāmetros obtidos pelas determinações realizadas na base, meio e ponta dos colmos. Houve diferenca significativa entre os tratamentos em cana planta e soca. Entre variedades, houve diferença estatistica apenas em cana soca.

A tabela 2 mostra o diāmetro médio dos colmos em cada tratamento. Estes dados, comparados através do teste de Tukey demonstram a igualdade estatistica entre os tratamentos TTG e TTT, em cana planta e soca, sendo os resultados mais evidentes nos dados coletados na cana soca, quando ambos (TTT e TTG) diferiram estatisticamente do tratamento RSD.

A redução do diâmetro mēdio dos colmos, provoca do pelo RSD é claramente demonstrada. Calculou-se ganhos devidos aos tratamentos térmicos (TTG e TTT) em $2,7 \%, 1,1 \%$ e $5,4 \%$ para cana planta, nas variedades CB41-76, NA56-79 e CB49-260, respectivamente. Em cana soca, os ganhos foram da ordem de $4,4 \%, 4,9 \%$ e $5,3 \%$, respectivamente, mostrando o efeito do RSD na soca com maior evidéncia, como era esperado. Estes dados de finem quantitativamente a observação de STEINDL (1961) quanto à influéncia do RSD na ocorrēncia de colmos mais finos.

\subsubsection{Altura mēdia dos colmos $(\mathrm{cm})$}

Ma avaliação de altura média dos colmos, a análise de variāncia (apēndice 3 ) mostroudiferencas estatisticas entre variedades e entre tratamentos, tanto em cana planta co- 
mo em soca. A interação variedades e tratamentos apresentou sig nificância a $5 \%$ de probabilidade apenas em cana soca.

0 desenvolvimento dos colmos de cana-de-açūcar em relação à altura e ao diâmetro, são os parâmetros mais afetados pelo RSD, segundo constatações de STEINDL (1961).

Os resultados apresentados na tabela 3 , quanto

à altura média dos colmos, mostram igualdade estatistica entre os tratamentos TTT e TTG e ambos diferentes do RSD em cana planta e soca. O desenvolvimento superior dos colmos em altura calculado pela média dos tratamentos térmicos (TTG e TTT) em relação às canas doentes, mostraram ganhos de $8 \%, 6 \%$ e $6 \%$ nas va riedades CB41-76, NA56-79 e CB49-260 respectivamente, em cana planta e $14 \%$, $19 \%$ e $7 \%$ em cana soca.

os indices de danos ao crescimento dos colmos apresentados está bastante próximo ao calculado por SINGH (1974), que definiu $\in m$ 6,7\% o decréscimo em altura, como mëdia de dez variedades analisadas, em plantas de primeiro corte.

4.1.4. Nümero de colmos industrializäveis

Pela anālise de variāncia (apêndice 4) realizada, pode-se afirmar que pelo menos duas das variedades diferiram entre si em cana planta e soca. Tambëm, pelo menos dois tratamentos foram diferentes entre si, porém, apenas em cana soca.

$\mathrm{Na}$ tabela 4 estão apresentadas as médias dos tratamentos calculadas em relação ao número de colmos por par- 
Tabela 3. Altura média em cana planta e soca de 3 variedades, com 3 tratamentos cada.

\begin{tabular}{lccc}
\hline & \multicolumn{3}{c}{ Altura média dos colmos $(\mathrm{cm})$} \\
\cline { 4 - 4 } RSD & To & corte - cana planta & TTT \\
\hline CB41-76 & 197 & 219 & 207 \\
NA56-79 & 208 & 226 & 214 \\
CB49-260 & 203 & 212 & 218 \\
Média & 203 & 219 & 213 \\
\hline CB41-76 & 188 & 219 & 208 \\
NA56-79 & 204 & 243 & 242 \\
CB49-260 & 206 & 218 & 221 \\
Média & 199 & 227 & 224 \\
\hline
\end{tabular}

$\operatorname{dms}(\Delta)$ e $s(\bar{m})$ para altura média

\begin{tabular}{cccccc}
\multicolumn{2}{c}{ Cana planta } & \multicolumn{3}{c}{ Cana soca } \\
\hline$\Delta 5 \%$ & $\Delta 1 \%$ & $\mathrm{~s}(\overline{\mathrm{m}})$ & $\Delta 5 \%$ & $\Delta 1 \%$ & $\mathrm{~s}(\overline{\mathrm{m}})$ \\
\hline 7 & 9 & 2,15 & 10 & 12 & 2,77 \\
13 & 16 & 3,73 & 16 & 21 & 4,80 \\
\multicolumn{3}{c}{$\mathrm{CV}=4,32 \%$} & \multicolumn{3}{c}{$\mathrm{CV}=5,43 \%$}
\end{tabular}

RSD - Raquitismo da soqueira

TTG - Tratamento tērmico de gemas isoladas

TTT - Tratamento térmico de toletes de três gemas. 
Tabela 4. Número de colmos por hectare e número médio de colmos das parcelas experimentais, em dois cortes conse cutivos, para 3 variedades com 3 tratamentos cada.

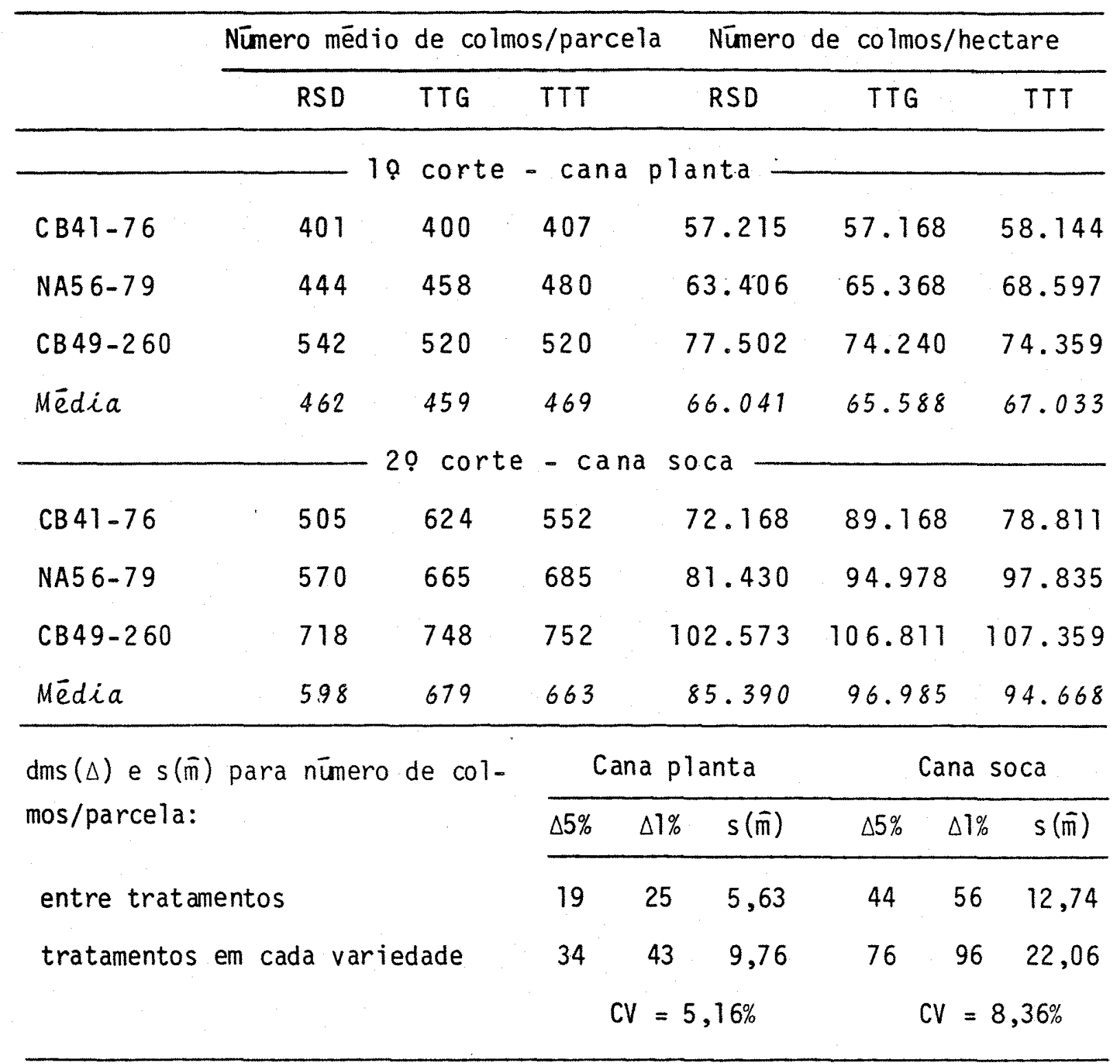

RSD - Raquitismo da soqueira

TTG - Tratamento térmico de gemas isoladas

TTT - Tratamento térmico de toletes de trēs gemas. 
cela e número de colmos por hectare.

As médias relativas ao nümero de colmos por par cela demonstram, atravēs do teste de Tukey, que independente de variedades, os tratamentos não diferiram entre si em cana planta. Na soca, os tratamentos TTT e TTG não diferiram e ambos foram significativamente diferentes do tratamento RSD.

Na variedade CB41-76 e CB49-260, em cana planta, os três tratamentos apresentaram-se iguais. Para a NA56-79 houve diferença significativa (5\%) entre os tratamentos RSD e TTT, com este apresentando pequena vantagem sobre os demais. Em cana soca, os tratamentos TTT e TTG foram iguais nas trēs variedades. Em relaça às canas doentes, houve diferenca apenas entre os tratamentos TTG e RSD na CB41-76; di ferença entre TTT e RSD na NA56-79 e igualdade entre TTT, TTG e RSD na CB49-260. Observou-se, entretanto, tendēncia de maior nümero de colmos por parcela para os tratamentos TTT e TTG em relação às canas doentes (RSD).

As observações de SINGH(1974) apresentando $31,5 \%$ de diminuicão no número de colmos industrializáveis não está coerente com o presente trabalho. E preferivel, por estas análises e nestas variedades, concordar com as afirmações de STEINDL (1961), que admitiu serem as perdas pelo RSD devido mais a outros fatores, do que a redução no número de colmos. Entretanto, o mesmo autor admitiu que em anos secos o número de colmos é reduzido, como observou-se no tratamento RSD em re lação do TTT e TTG na colheita da cana soca, quando o ano de 
1985 apresentou chuvas irreqularmente distribuidas (precipitacōes pluviométricas registradas, no apēndice 7).

Calculando-se o peso médio por colmo, a partir do peso das parcelas e número de colmos industrializáveis coIhidos (quadro) observou-se a nitida diferenca dos tratamentos térmicos (TTT e TTG) em relação às canas não tratadas, em conformidade com as anālises feitas para as avaliações de diâmetro e altura média dos colmos.

\begin{tabular}{llllllll}
\hline \multirow{2}{*}{ Variedades } & \multicolumn{3}{c}{ Cálculo de peso dos colmos } & \multicolumn{2}{c}{$(\mathrm{kg} /$ colmo) } \\
\cline { 2 - 7 } & \multicolumn{2}{c}{ 10 corte - cana planta } & \multicolumn{2}{c}{20 corte - cana soca } \\
\cline { 2 - 8 } & RSD & TTG & TTT & RSD & TTG & TTT \\
\hline CB41-76 & 0,89 & 1,06 & 0,99 & 0,66 & 0,76 & 0,71 \\
NA56-79 & 0,93 & 1,07 & 1,06 & 0,66 & 0,80 & 0,76 \\
CB49-260 & 0,85 & 0,99 & 1,05 & 0,61 & 0,71 & 0,70 \\
Médias & 0,89 & 1,04 & 1,03 & 0,64 & 0,76 & 0,72 \\
\hline
\end{tabular}

Pode-se avaliar em $16,3 \%$ o ganho em peso médio por colmo em cana planta e $15,6 \%$ em cana soca, quando as canas for am submetidas ao tratamento térmico, comparadas àquelas sem controle do RSD, para as 3 variedades utilizadas. Este indice é bastante superior ao obtido por SINGH(1974) em cana planta (menos $4,1 \%$ ), nas condições e variedades por ele empreqadas. 
4.2. Avałiação da eficiência dos sistemas de tratamento tér mico

4.2.1. Fluxometria de àgua atravēs dos colmos (nós)

Para cana planta e soca, as medidas de fluxo de àgua através dos colmos (m1/75 minutos), apresentam para 3 va-. riedades utilizadas, diferenca estatistica entre os tratamentos, indicando que pelo menos dois destes tratamentos, indican do que pelo menos dois destes tratamentos diferiram entre si (apêndice 5).

As mëdias de fluxo de ägua apresentados na tabe la 5 , com as respectivas diferencas minimas significativas pe10 teste de Tukey, permitem verificar que em cana planta, para as variedades CB49-260 e NA56-79, apenas o tratamento RSD dife riu dos demais, enquanto para a variedade CB41-76 os trés trata mentos diferiramentre si. Em cana soca, para as trés variedades estudadas, somente o tratamento RSD diferiu dos demais ao nivel de $1 \%$ de probabilidade.

0 método de avaliacão da resistência de varieda des de cana-de-açucar ao RSD, pelo da medida do fluxo de āgua atravês dos colmos, conforme metodologia concebida por TEAKLE et alii (1975) e ampliada por VALARINI (1978), permite numa mesma variedade, determinar o grau de contaminação pelo RSD, uma vez que existe correlação positiva na diferenca de va zão em colmos sadios e doentes (VALARINI, 1978; DOUGLAS, 1981 

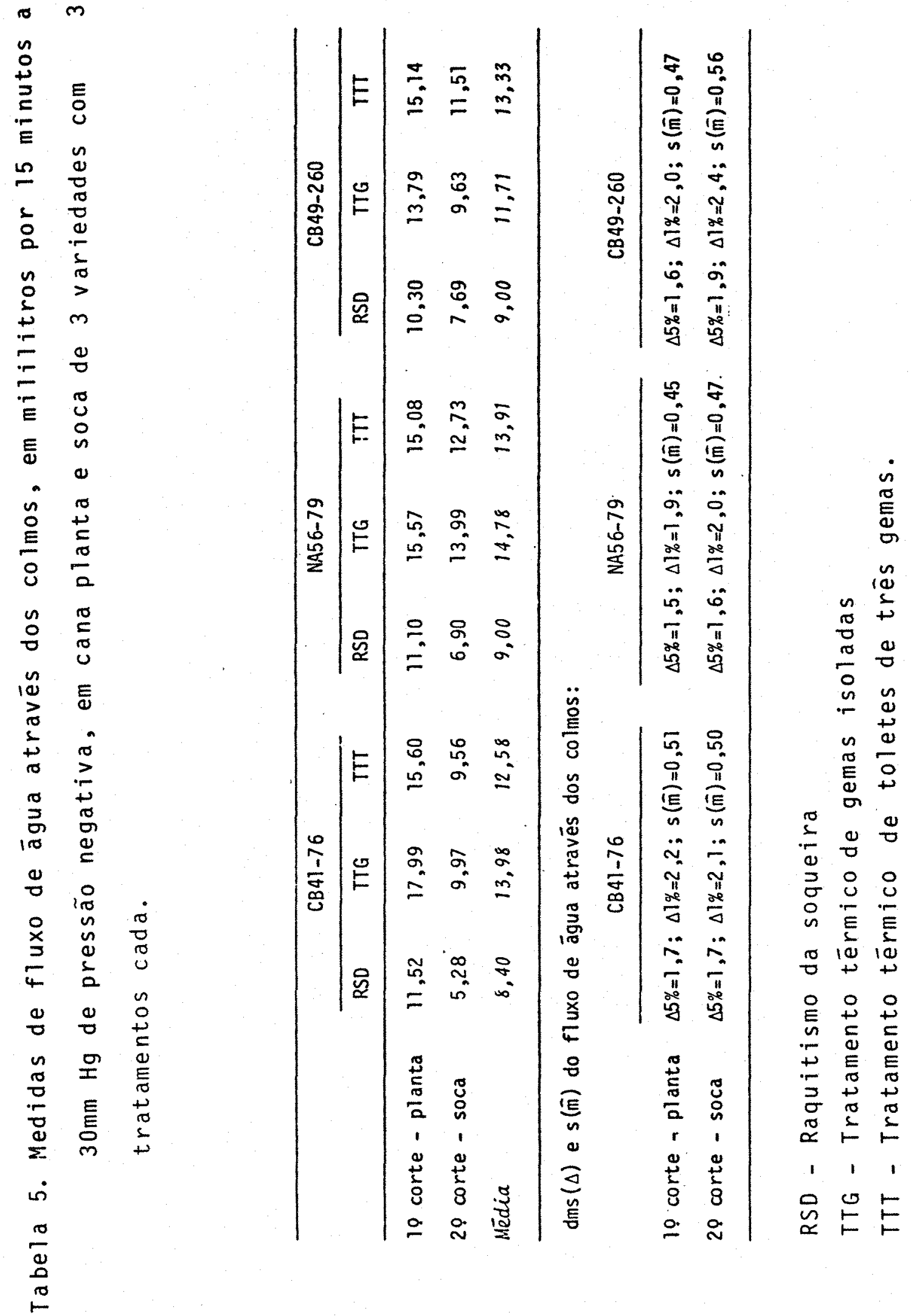
e CRUZ, 1983) e proporcionalidade direta entre vazão de āgua através dos colmos e o número de vasos funcionais do xilema.

Os elementos mostrados na tabela 5 , conseguidos atravēs de amostragem intensiva (180 determinaçōes por varieda de em cada tratamento) e analisados estatisticamente, permitem avaliar comparativamente os tratamentos estudados em dois ciclos sucessivos da cana-de-acúcar. Assim, em cana planta e soca, observou-se a maior vazão das canas consideradas sadias (TTT e TTG) sobre as canas doentes (RSD) não tratadas termicamente, como também nas mëdias dos tratamentos nos dois cortes sucessivos.

Sabe-se que os sintomas de RSD revelam-se com maior intensidade nas soqueiras. Tal fato foi constatado, pois na soca, as plantas tratadas termicamente pelos 2 sistemas apresentaram vazão de àgua atravēs dos colmos significativamen te superiores às plantas não tratadas. Conforme verificou-se, também, essas plantas tratadas apresentaram na soca nitido desenvolvimento maior em altura e diâmetro médio dos colmos, com paradas às plantas testemunhas.

4.2.2. Avaliação de sintomas vasculares do RSD

A tabe 1 a 6 apresenta a tabulaça dos resultados obtidos, na avaliacão de sintomas vasculares nos colmos, cuja comparação aritmētica define as tendências de ocorrência de sintomatologia caracteristica do RSD, para os tratamentos e va 


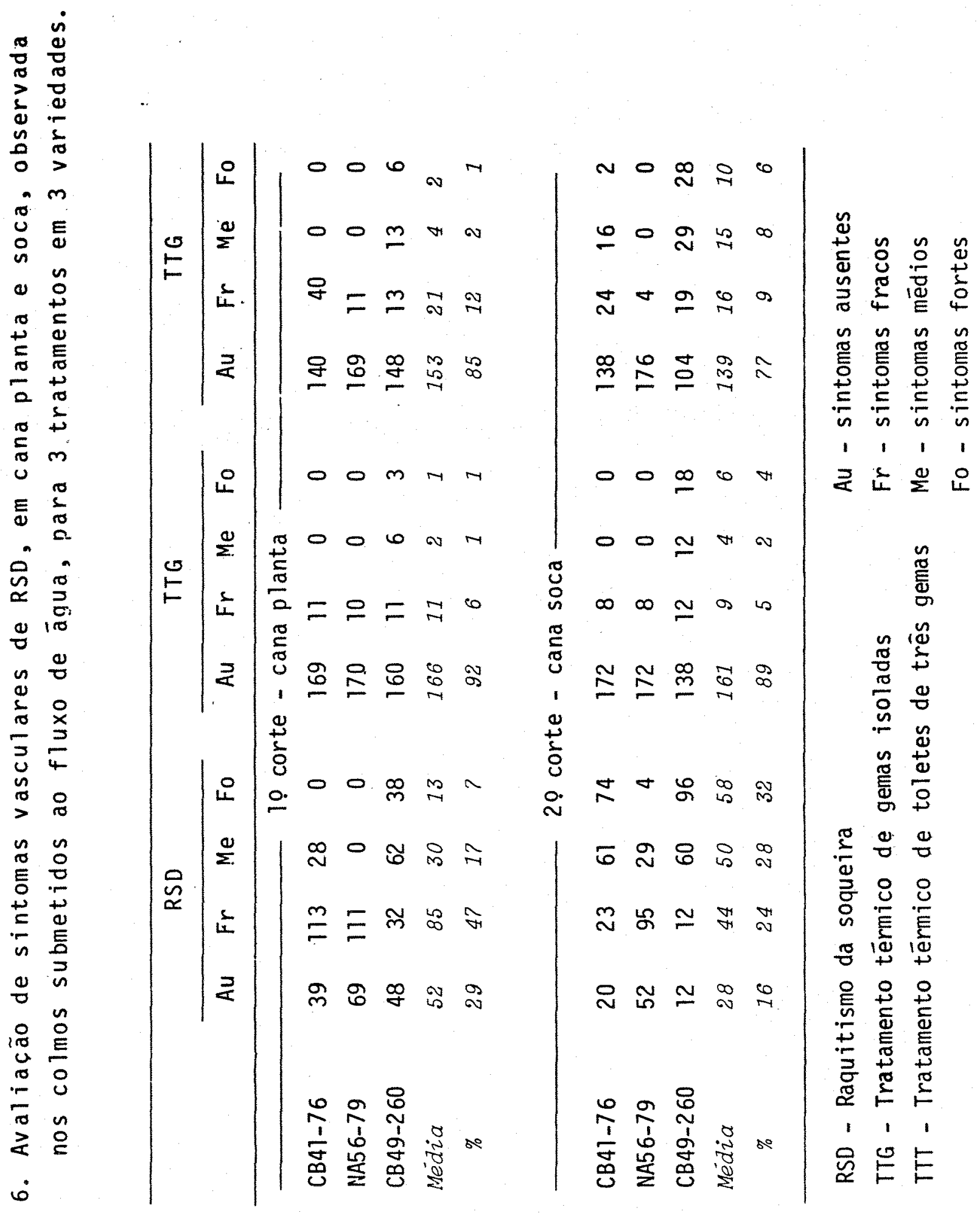


riedades analisados.

Embora considerado insatisfatōrio para, isolada mente, detectar a ocorrēncia de RSD, os sintomas vasculares em algumas variedades, podem ser utilizados como diagnōstico rāpi do, no campo. E necessärio, entretanto, bom treinamento visual da sintomatologia interna de RSD e diferenciacão para a ocorrência de outras doencas vasculares.

Os dados da Tabela 6 mostram diferencas marcantes na manifestação de sintomas vasculares na população de col mos doentes (RSD) e sadios (TTT e TTG). Observou-se ausēncia de sintomas em $29 \%$ dos colmos analisados com RSD da cana planta, e em $16 \%$ na cana soca, enquanto os tratamentos térmicos apresentaram indices calculados de $85-92 \%$ de ausência de sinto mas na cana planta e 77-89\% em cana soca. Para os tratamentos tērmicos comparados (TTT e TTG) hā nîtida tendēncia decrescente de aparecimento dos sintomas, da ausēncia dos sintomas para os mais evidentes, o que ocorre de forma inversa no tratamento RSD, notadamente em cana soca.

Analisando-se os padrões de ocorrēncia de RSD em duas classes apenas, com a associaça dos sintomas ausente e fraco $(A u+F r)$ comparados com médio e forte (Me + Fo), e possivel avaliaça mais evidente das leituras. Desse modo, em cana-planta, calculando-se percentualmente, os tratamentos tēr micos (TTG e TTT) apresentam $98 \%$ e $97 \%$, respectivamente, de sintomas ausente/fraco, contra $76 \%$ dos colmos com RSD. Na soca os tratamentos TTG e TTT apresentaram $94 \%$ e $86 \%$, respectivamen 
te, de sintomas ausente/fraco, contra apenas $40 \%$ do tratamento RSD, caracterizando a evolução da doenca nas soqueiras de cana-de-a cūcar.

4.2.3. Contagem de bactērias (ciavibacter xyli subsp. $x y(i)$ atravēs de microscopia de contraste de fa se

Estão apresentadas nas tabelas 7,8 e 9 , as con tagens de bactērias realizadas nas variedades CB41-76, NA56-79 e CB 49-260, respectivamente, atravēs da microscopia de contras te de fase. Os colmos amostrados para serem submetidos à microscopia, for am analisados novamente pela fluxometria (vazão de àgua atravēs dos nós) e ocorréncia de sintomas vasculares, cujas avaliações constam das tabelas.

Comparando-se as mëdias apresentadas nessas tabelas têm-se que a contagem do nümero de bactérias no sucó do xilema dos colmos das variedades utilizadas, apresentou avalia cão rigorosamente idēntica para os tratamentos TTT e TTG, e bastante diferenciado das características da populacão de col:mos doentes (RSD).

Em comparacão à avaliação do fluxo de àqua atra vēs dos nōs, feita em amostragem mais intensiva (item 4.2.1), as medicões de vazão realizadas nos colmos submetidos à micros copia apresentaram-se rigorosamente dentro dos comentārios já desenvolvidos naquele item. Da mesma forma, a caracterizacão 

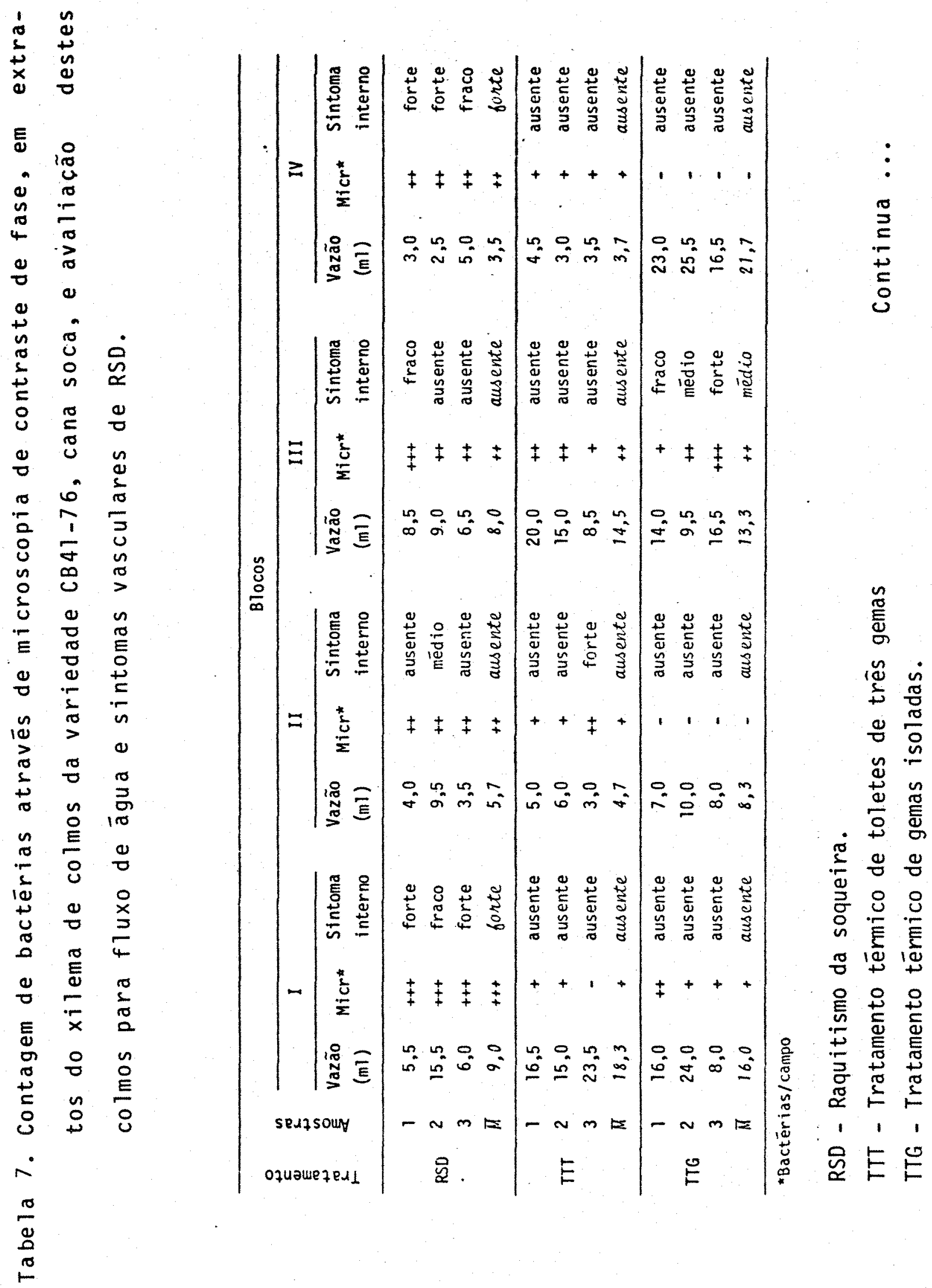


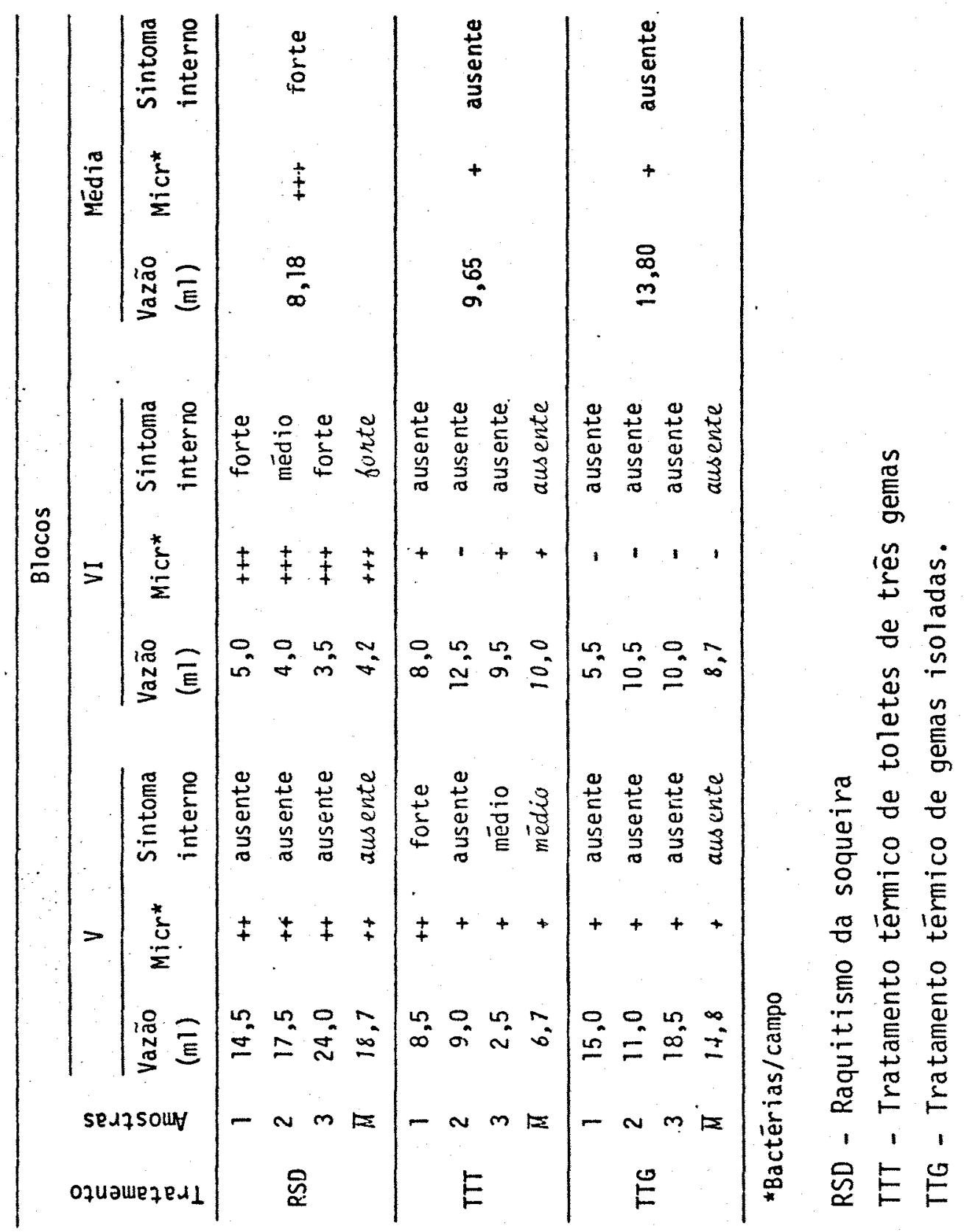



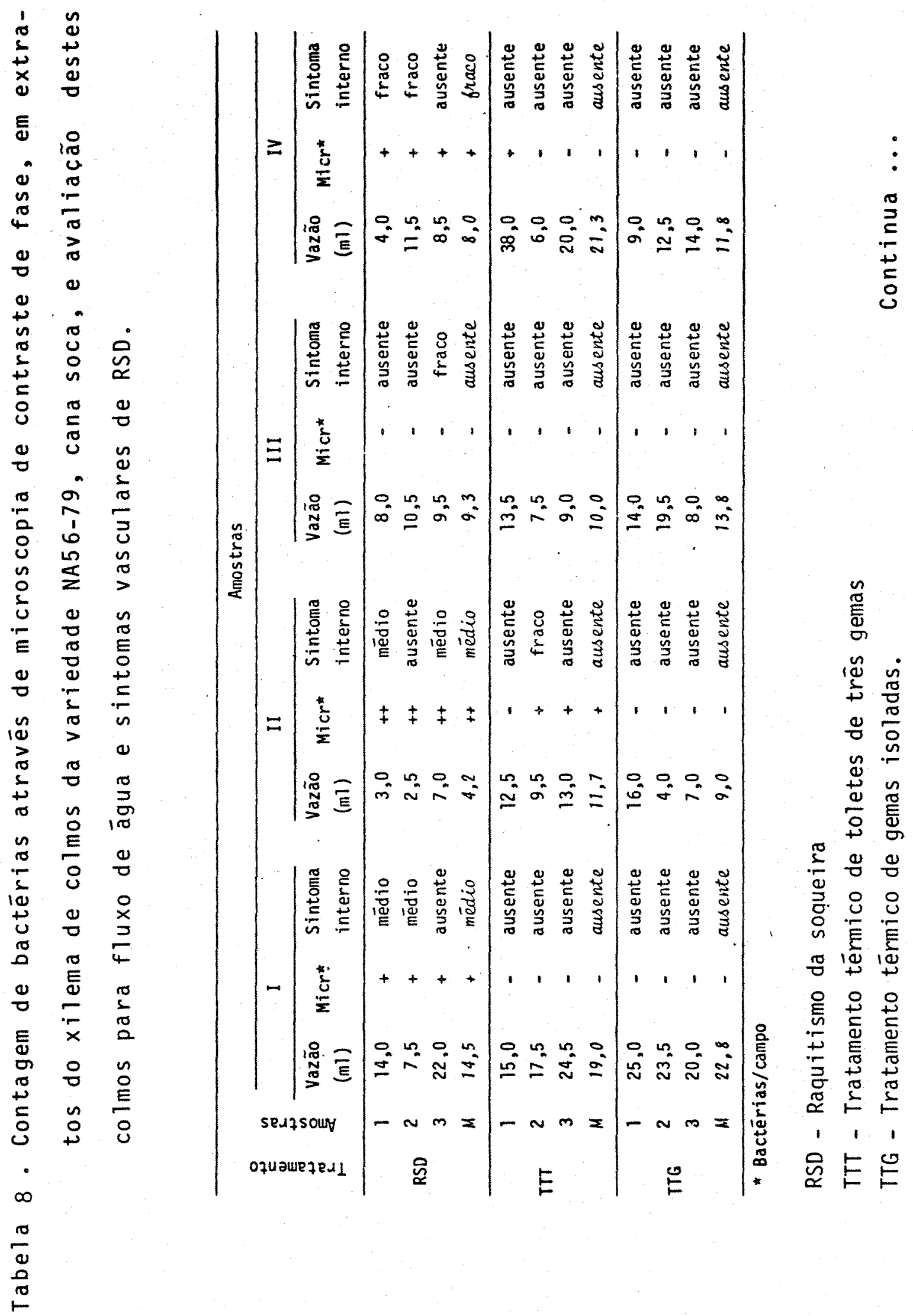


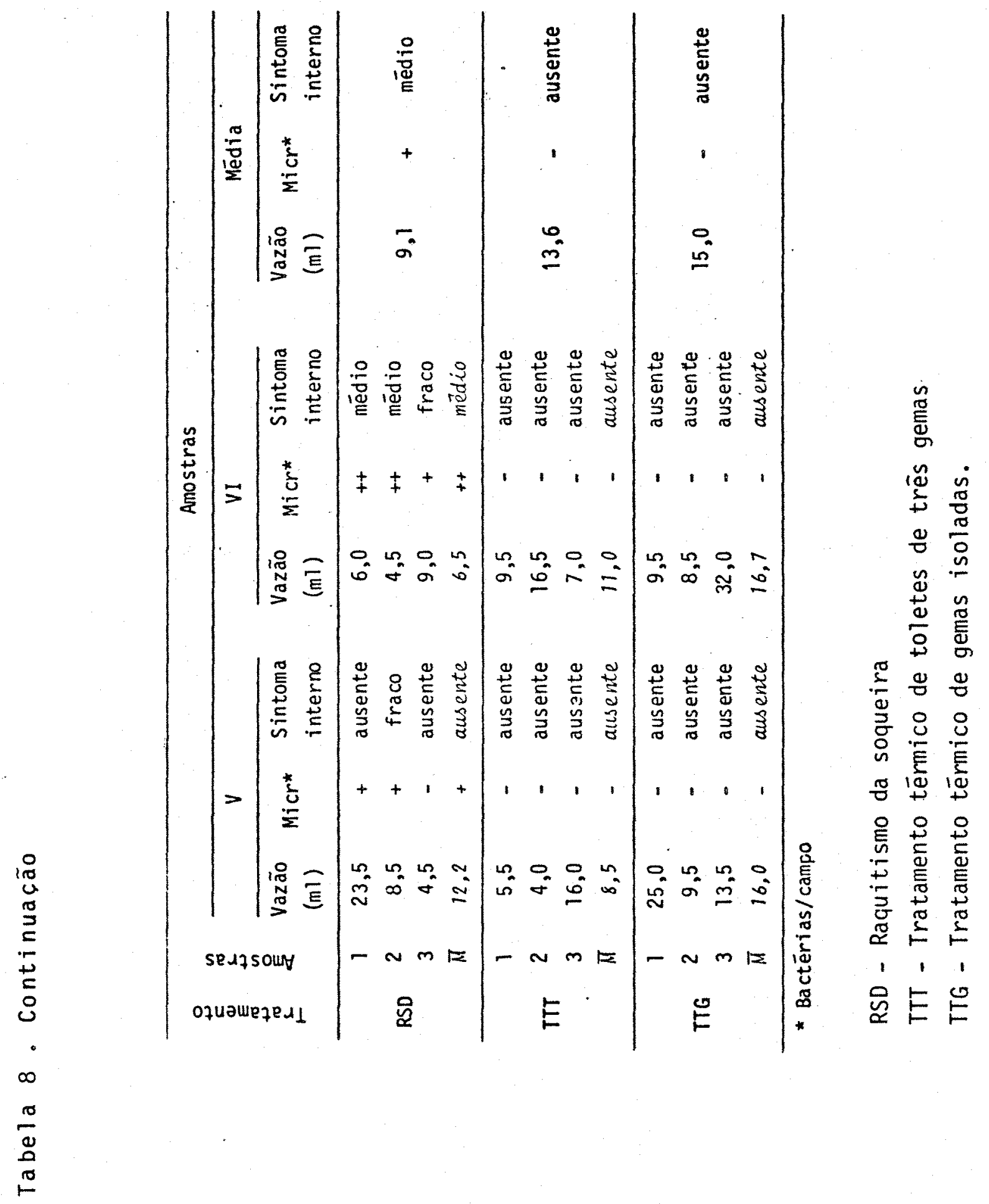




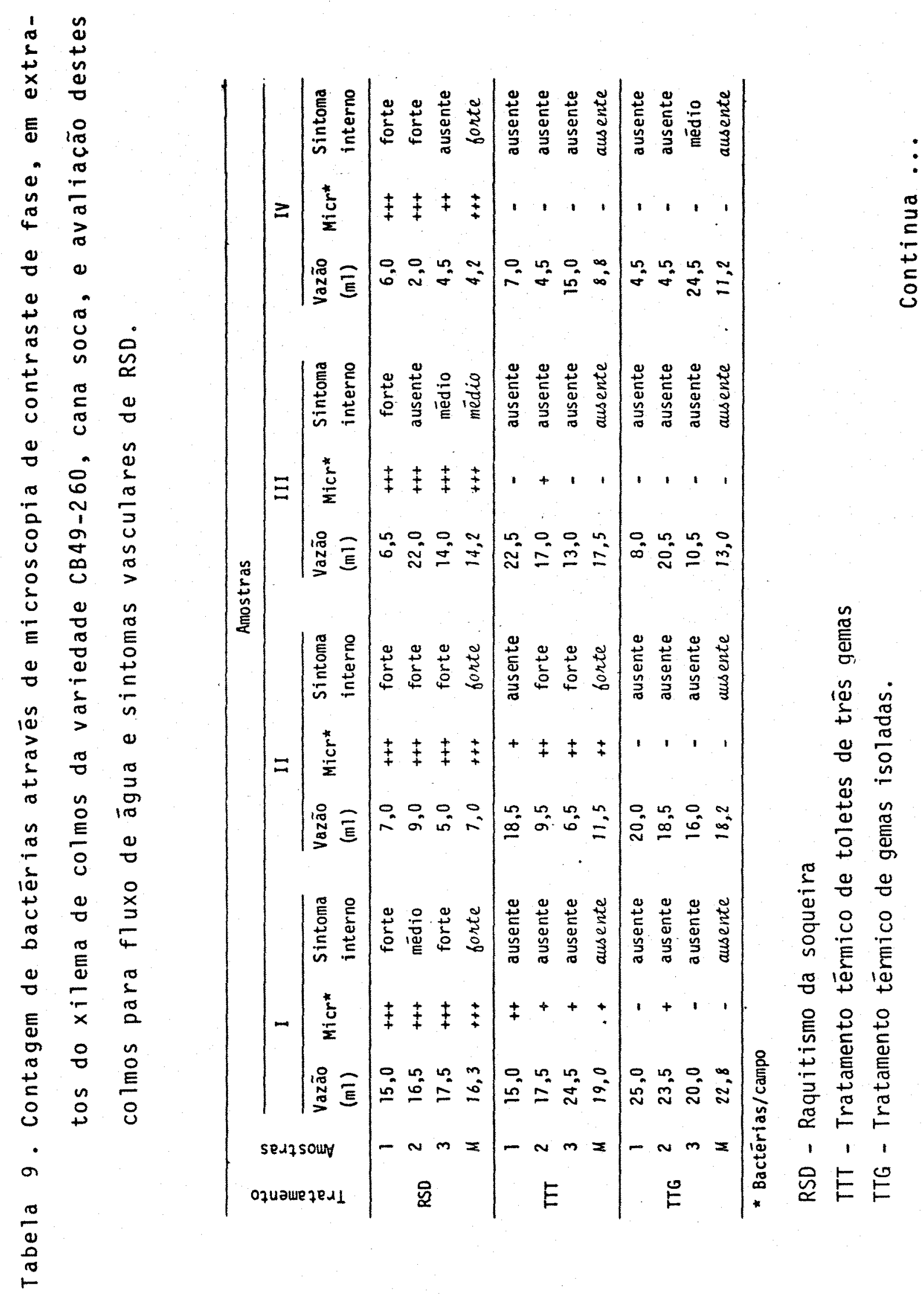




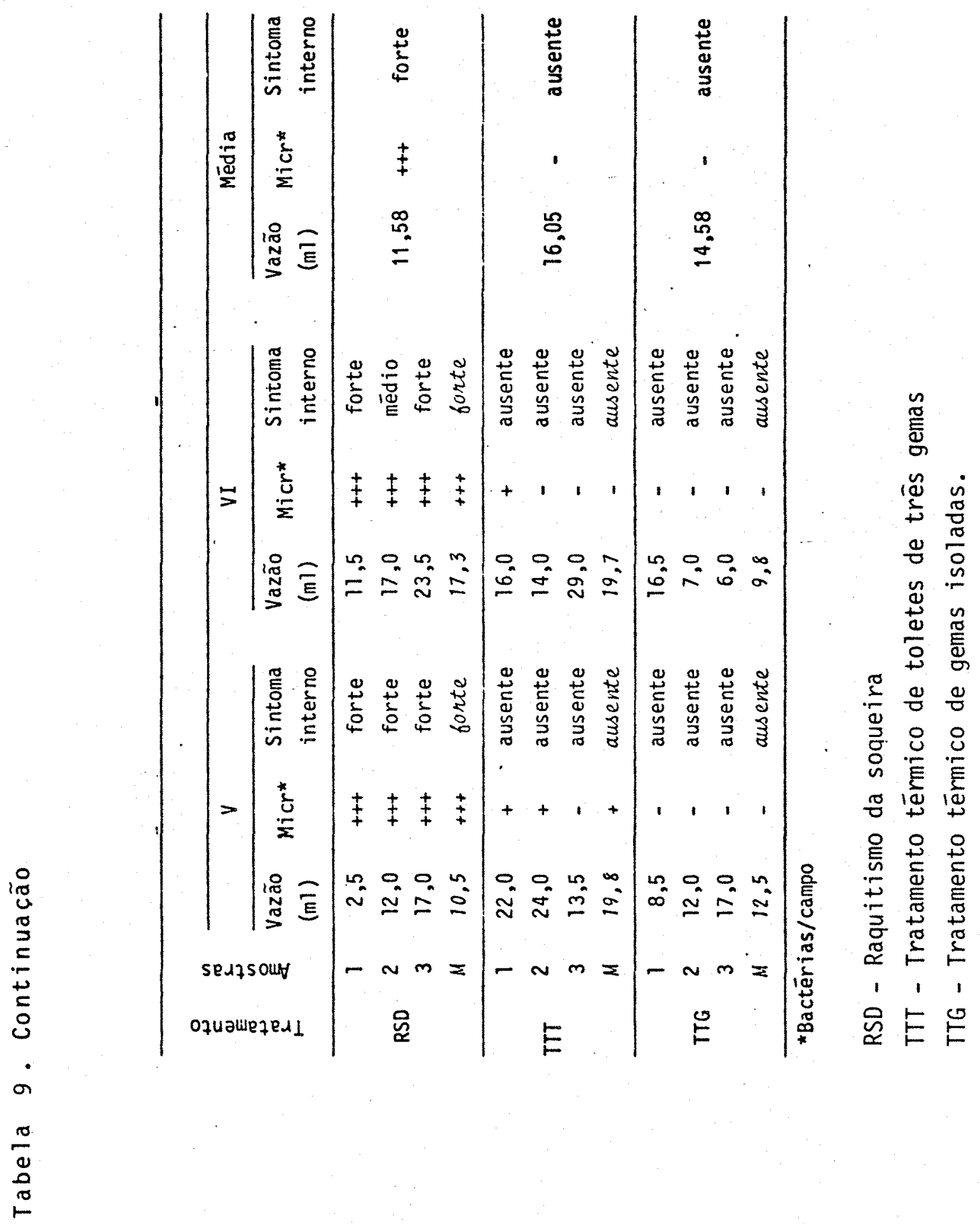


dos sintomas vasculares mostrados nas tabelas 7,8 e 9 , acompa nham a anālise desenvolvida no item 4.2 .1 .

A microscopia de contraste de fase, conforme as indicações de GILLAPIE et aliz (1973 e 1976), BAILEY (1981), BAILEY e FOX (1985) e SANGUINO et ali (1984), avalia com precisão a ocorrência das bactērias clavibacter xyli em material (suco) extraido do xilema dos colmos da cana-de-acūcar. Os ele mentos apresentados nas tabelas 7,8 e 9 demonstram claramente a situação dos colmos com RSD das 3 variedades estudadas, com leituras bastante diferenciadas em relação aos tratamentos tér micos (TTT e TTG). Entre os tratamentos térmicos comparados (TTT e TTG), portanto colmos com menor intensidade de infestacão de bactérias, a microscopia de contraste de fase possibil ta a deteccão de escapes, normalmente esperado para as condicões fitossanitárias destas variedades antes do tratamento, e a realização de somente uma operação termoterāpica.

A perfeita correlacão de prejuizos causados peIo RSD (toneladas de colmos por hectare) com a avaliacão feita pelo fluxo de àģua atravēs dos nōs e pela da microscopia de contraste de fase, asseguram a eficiência particular dos siste mas de tratamento térmico em gemas isoladas (TTG) e em toletes de 3 gemas (TTT), e a iqualdade de acão destes equipamentos na inativaç̃o do agente causador do RSD em cana-de-açucar. 
5. CONCLUSOES

1. O raquitismo da soqueira interfere drasticamente na produtividade agricola da cana-de-açucar, devido prin cipalmente à redução da altura e diâmetro dos colmos.

2. O fluxo de àqua através dos colmos e a avaliacão da ocorrēncia de bactérias causadoras do raquitismo da soqueira no xilema dos colmos, atravēs da microscopia de contraste de fase, constituem-se métodos eficientes de avaliacão da incidência da doença em cana-de-açúcar, principalmente quan do são conhecidas as caracteristicas da variedade infectada, e sua reação de tolerância ao raquitismo da soqueira (manifesta cão de perdas nas condicões de campo).

3. Os sistemas de tratamento térmico em gemas isoladas e em toletes de 3 gemas são igualmente eficientes no 
controle do raquitismo da soqueira em cana-de-acūcar.

4. O sistema de tratamento tērmico em toletes de 3 gemas, comparado ao sistema de gemas isoladas, apresenta melhor eficácia operacional, devido ao menor número de operacões e maior rapidez na implantacão da primeira fase de campo (viveiro primārio). 


\section{LITERATURA CITADA}

ABBOTT, E.V., 1963. Problems in sugar cane disease control in Louisiana. In: XI Congress of the International Society of Sugar Cane Technologosists', Mauritius, p. 739-742.

ANTOINE, R., 1957. Cane diseases. Review of Appl. Mycology.

Farnham Roya 1, 36:616-617.

ANTOINE, R., 1958. A staining technique for detecting ratoon stunting disease in sugar cane. Nature. London, 181:276277.

ANTOINE, R. e C. RICAUD, 1964. Cane diseases. In: MAURITIUS SUGAR INDUSTRY RESEARCH INSTITUTE. Port Louis. Annual Report 1963. Port Louis, p. 75-89.

BAILEY, R.A., 1976. Some observations on the bacterium associ ated with ratoon stunting disease of sugarcane. Proceedings 
of the South African Sugar Technologists' Association. Mount Edge combe, 50:1-5.

BAILEY, R.A., 1981. Rapid diagnostic service for RSD. South African Sugar Journal. Durban, 65:567-568.

BAILEY, R.A. e P.H. FOX, 1985. A large-scale diagnostic service for ratoon stunting disease. Sugar Journal. New orleans, $47: 12-17$.

BECHET, G.R., 1976. Ratoon stunting disease and rapid diagnostica techniques. South African Sugar Journal. Durban, $60: 539-545$.

BENDA, G.T.A., 1972. Hot-water treatments for mosaic virus and ratoon stunting disease control. Sugar Journal. New Orleans, 34:1-23.

BENDA, G.T.A. e C. RICAUD, 1978. The use of heat treatment for sugarcane disease control. In: XVI Congress of the International Society of Sugar Cane Technologists, São Pau10, v.1, p. 484-496.

BRIEGER, F.0., 1967. Raquitismo da soqueira. Boletim Informativo COPERESTE. Ribeirão Preto, 6:1-5.

CARVALHO, P.C.T., 1978. Importāncia das doenças das plantas, In: - Manual de Fitopatologia. São Paulo, Editora Agronômica Ceres, v. 1, cap. 2, p. 15-25.

CHAGAS, P.R.R., 1985. Método de coloração pelo fluxo transpiratório aplicado na determinacão de infeccão do raquitismo da soqueira em cana-de-açúcar. Piracicaba, ESALQ/USP, 123p. (Dissertação de Mestrado).

CHEN, C.T.; S.M. LEE e M.J. CHEN, 1975. Small coryneform bac- 
teria in ratoon-stunted sugarcane. Sugarcane Pathologists'

Newsletter. Honolulu, $(13 / 14): 6-8$.

CHU, H.T.; K.C. LING e S.M. LEE, 1960. Ratoon stunting disease control in Taiwan. In: X Congress of the International Society of Sugar Cane Technologists, Hawaii, p.1072-1077. COCHRAN, B.J.; M. MAYEUX e R. STEIB, 1976. Development of an aerated steam system for the control of ratoon stunting disease in sugar cane. Proceedings American Society of Sugar Cane Technologists. Florida, 5:123-126. CRUZ, M.M., 1983. Avaliação da resistēncia ao raquitismo da soqueira e a escaldadura das folhas pelo método de vazão de àgua em colmos de cana-de-açūcar. Piracicaba, ESALQ/USP, 52p. (Dissertação de Mestrado).

DAMANN Jr., K.E., 1976. A possible causal organism of ratoon stunting disease. Proceedings of the American Society of Sugar Cane Technologists'. Florida, $\underline{5}: 53-55$.

DAMANN Jr., K.E., 1981. La enfermedad de1 raquitismo del retoño (RSD) de la caña de azucar; la bacteria causante. Tecnologia GEPLACEA. México, (2):149-152.

DAMANN Jr., K.E. e K.S. DERRICK, 1976. Bacterium associated with ratoon stunting disease in Louisiana. Sugarcane Pathologists' Newsletter. Aiea, $(15 / 16): 20-22$.

DAMANN Jr., K.E.; K.S. DERRICK; A.G. GILLASPIE Jr.; D.B. FONTENOT E J. KAO, 1978. Detection of the RSD-associated bacterium by serologically specific electron microscopy. In: XVI Congress of the International Society of Sugar Cane Technologists, São Paulo, v. 1, p. 433-437. 
DAVIS, M.J.; A.G. GILLASPIE Jr.; R.W. HARRIS, R.H.LAWSON, 1980. Ratoon stunting disease of sugarcane; isolation of the causal bacterium. Science. Washington, 210:1365-1367. DAVIS, M.J.; A.G. GILLASPIE Jr.; A.K. VIDAVER E R.W. HARRIS, 1984. Clavibacter; a new genus containing some phytopathogenic coryneform bacteria, including clavibacter xylisubsp. xyli sp. nov. and clavibacter xyli subsp. cynodontis subsp. nov., pathogens that cause ratoon stunting disease of sugarcane and bermudagress stuting disease. International Journal of Systematic Bacteriology. Washington, 34:107-117. DODSON, A.K., 1973. Equipamento para tratamento térmico desen volvido no PLANALSUCAR. Planalsucar em Noticias. Rio de Janeiro, (12):1-4.

DOUGLAS, R.A., 1981. Correlação entre vazão de àgua e resistência ao raquitismo da soqueira em cana-de-açucar. Piraci caba, ESALQ/USP, 57p. (Dissertação de Mestrado).

DROUGHT devastates RSD infected cane, 1980. South African Sugar Journal. Durban, 64:405-408.

FARRAR, L.L., 1957. A chemical test for ratoon stunting disease of sugarcane. Phytopathology. St. Paul, 47:10.

FARRAR, L.L., 1958. Studies on the ratoon stunting disease of sugarcane in Louisiana. Review of Applied Mycology. Farnham Royal, 37:309.

FORBES, I.L. e K.C. LING, 1960. Particles associated with the ratoon stunting disease of sugarcane. Sugar Journal. New Orleans, $23: 15$.

GILLASPIE Jr., A.G., 1971. Ratoon stunting disease virus; 
problems in purification. Proceeding American Society of Sugar Cane Technologists. Florida, 1:52-56.

GILLASPIE Jr., A.G.; J.E. IRVINE e R.L. STEERE, 1966. Ratoon stunting disease virus; assay technique and partial purification. Phytopathology. St. Pau1, 56:1426-1427.

GILLASPIE Jr., A.G.; J.E. IRVINE e R.L. STEERE, 1967. Ratoon stunting disease. Sugar Journal. New Orleans, 29:18-19. GILLASPIE Jr., A.G.; R.E. DAVIS E J.F. WORLEY, 1973. Diagnosis of ratoon stunting disease based on the presence of a specific microorganism. Plant Disease Reporter. Washington, $\underline{57}: 987-990$.

GILLASPIE Jr., A.G.; R.E. DAVIS e J.F. WORLEY, 1974. Nature of the ratoon stunting disease agent. In: XV Congress of the International Society of Sugar Cane Technologists, Durban, p. 218-224.

GILLASPIE Jr., A.G.; G. FLAX e H. KOIKE, 1976. Relationship between numbers of diagnostic bacteria and injury by ratoon stunting disease in sugarcane. Plant Disease Reporter. Was $\underline{h}$ ington, 60:573-575.

GILLASPIE Jr., A.G.; M.J. DAVIS, R.W. HARRIS e R.H. LAWSON, 1981. Isolation and pathogenicity of the ratoon stunting disease bacterium. International Sugar Journal. Bucks., 83: $324-326$.

HARRIS, R.W. e A.G. GILLASPIE Jr., 1978. Immunofluorescent diagnosis of ratoon stunting disease. Plant Disease Reporter. Washington, 62:193-196.

HUGHES, C.G., 1974. The economic importance of ratoon stunt- 
ing disease. In: $X V$ Congress of the International Society of Sugar Cane Technologists, Durban, v. 1, p. 213-217. HUGHES, C.G., 1978. Diseases of sugarcane; a review. Pans. London, 24:143-159.

HUGHES, C.G. E D.R.L. STEINDL, 1955. Ratoon Stunting Disease of Sugar Cane. Queensland, BSES, 54p. (Tech. Comm., 2). IAA/PLANALSUCAR. Piracicaba, 1976. Raquitismo da soqueira. In: __ Relatörio Anual 1975. Piracicaba, p. 35-37. KAISER, W.J. E A.H. RAMOS, 1980. Association of a bacteriumlike organism with ratoon stunting disease of sugarcane in Kenya. Sugarcane Pathologists' Newsletter. Réduit, (24) $: 14-16$.

KAIIIUNTEN, H. e S. WAKIMOTO, 1976. Coryneform bacteria found in $x y 1$ em of the ratoon diseased sugarcane. Phytopathological Society of Japan. Annals. Tokio, 42:500-503.

KING, N.J., 1954. Uma causa para o decitinio das variedades. Brasil Acucareiro. Rio de Janeiro, 43:62-65.

KING, R.F. e G.M. THOMSON, 1972. A note on a survey of commercially a available hot water treatment tanks for the con trol of ratoon stunting disease (RSD). In: XLVI Annual Congress of the South African Sugar Cane Technologists" Association, Mount Edgecombe, p. 1-2.

LIU, L.J., 1978. Association of a small coryneform bacterium with RSD in Puerto Rico. Sugarcane Pathologists' Newsletter. Reduit, $(20): 4$.

LIU, L.J.; A. CORTES-MONLLOR; K. MARAMOROSCH; H. HIRUMI; J.E. PEREZ e J. BIRD, 1974. Isolation of an organism resembling 
Xanthomonas vasculorum from sugarcane effected by ratoon stunting disease. In: XV Congress of the International Society of Sugar Cane Technologists, Durban, p. 234-240. LOPEZ-ROSA, J.H. e J. ADSUAR, 1970. Effect of stunting disease on yield of some sugarcane varieties in Puerto Rico. Journal Agricultural University Puerto Rico. Rio Piedras, 54:149-160.

MAGO N., P.; A. APONTE e L. RODRIGUEZ, 1984. Efecto de la termoterapia sobre el raquitismo de las socas y la germinacion de la caña de azūcar. Caña de Azũcar. Maracay, 2 :8088.

MARAMOROSCH, K.; B. PLAVSIC-BANJAC; J. BIRD E L.J. LIU, 1973. Electron microscopy of ratoon stunted sugar cane; microorganism in xylem. Phytopathology. St. Paul, 77:270-273.

MATSUOKA, S., 1971a. Incidéncia do vírus do raquitismo da soqueira em canas provenientes de material propagativo tratado termicamente. Campinas, Instituto Agronōmico, $2 p$. MATSUOKA, S., 1971b. Virus do raquitismo da soqueira. Piraci caba, ESALQ/USP, 9p.

MATSUOKA, S., 1972. Raquitismo da soqueira da cana-de-açucar; diagnose da moléstia e estudos sobre o seu agente causal.' Piracicaba, ESALQ/USP, 77p. (Tese de Doutoramento)

MATSUOKA, S., 1975. Disseminacão e controle do raquitismo da soqueira da cana-de-açucar. Summa Phytopathologica. Piracicaba, 1:245-257.

MATSUOKA, S., 1976. Recuperação da produtividade de variedades de cana-de-açucar pelo tratamento térmico de toletes 
(1). Brasil Acucareiro. Rio de Janeiro, 87:20-24.

MATSUOKA, S., 1984a. Benefícios da prätica de tratamento tērmico da muda de cana-de-açücar e eficiēnciados dois métodos existentes no Brasil. Cadernos PLANALSUCAR. Piracicaba, (3):22-24.

MATSUOKA, S., 1984b. Longevidade do efeito do tratamento tērmico em canas infetadas pelo raquitismo da soqueira. Araras, IAA/PLANALSUCAR. COSUL, $19 p$.

MATSUOKA, S., 1984c. Relatörio técnico-científico. Piracicaba, IAA/PLANALSUCAR. SUPER, 18p. (Processo SAD/GOD $40.5460 / 84 \mathrm{AG})$.

MUNIYAPPA, V. e V.N. SETTY, 1982. Reaction of sugarcane varieties to ratoon stunting disease. Sugar Pathologists' Newsletter. Reduit, (29):41-44.

PLAVSIC-BANJAC, B. e K. MARAMOROSH, 1972. Electron microscopy of the xylem of ratoon stunted sugarcane. Phytopathology. St. Paul, 62:498-499.

RICAUD, C., 1968. Ratoon stunting disease. In: MAURITIUS SUGAR INDUSTRY RESEARCH INSTITUTE. Port Louis. Annual Report 1967. Port Louis, p. 54.

RICAUD, C., 1974. Problems in the diagnosis of ratoon stunting disease. In: $X V$ Congress of the International Society of Sugar Cane Technologists, Durban, v. 1, p. 241-249.

RICAUD, C.; S. SULLIVAN E J.C. AUTREY, 1976a. Presence of the RSD-Associated Bacterium in Mauritius. Sugarcane Pathologists' Newsletter. Aiea, (17):37-39.

RICAUD, C.; S. SULLIVAN E J.C. AUTREY, 1976b. Systemic in- 
fections of sugar cane by the bacterium associated with symptoms of ratoon stunting disease. Revue Agricole et Sucriere de Maurice. Réduit, 55:159-162.

ROTH, G. E C. WHITEHEAD, 1965. Virus diseases and sugarcane. South African Sugar Journal. Durban, 49:675-683.

SANGUINO, A.; V.A. MORAES e O.T. SANTOS FILHO, 1984. Diagnōs tico do raquitismo da soqueira em colmos de cana-de-açúcar. In: II Seminārio de Tecnologia Agronômica, Piracicaba, CoPERSUCAR, p. 250-253.

SASA. Mount Edgecombe, 1976. Ratoon stunting disease. In: - Annual Report 1975-76. Mount Edgecombe, p. 63-64.

SASA. Mount Edgecombe, 1979. RSD diagnosis and surveys. In: - Annual Report 1978-79. Mount Edgecombe, p. 68-69

SCHEXNAYDER, C.A., 1960. The use of a sugarcane "test plant" as a means of detecting the presence of ratoon stunting dis eases in sugarcane. In: X Congress of the International Society of Sugar Cane Technologists, Hawaii, p. 1068-1072. SILVA, I.M., 1974. Hot water treatment of single buds for ratoonstunting disease control. Sugarcane Pathologists' Newsletter. Durban, $(11 / 12): 32-33$.

SILVA, W.M., 1976. Termoterapia em gemas isoladas assegura 0 controle do raquitismo. Boletim Técnico COPERSUCAR. São Pauto, (1):12-14.

SINGH, G.R., 1974. Studies on yield of cane and juice quality fue to ratoon stunting of sugarcane in India. Indian Sugar. New Delhi, 24:623-629.

SINGH, K., 1967. Heat therapy of sugarcane. Indian Sugar. 
New Delhi, 17:181-186.

SINGH, R.G., 1969. An indicator sugarcane variety for ratoon stunting disease. Current Science. Bangalore, 38:221-222. STEIB, R.J. e S.J.P. CHILTON, 1968. Ratoon stunting disease can and must be controlled in Louisiana. Sugar Bulletin. New Orleans, $46: 5-7$.

STEINDL, D.R.L., 1961. Ratoon stunting disease; causal agent, probably a virus. In: MARTIN, J.P.; E.V. ABBOTT e C.G. HUGHES. Sugar-cane Diseases of the World. Amsterdam, Elsevier, chap. 20, p. 433-459.

STEINDL, D.R.L., 1974a. Methods used in the identification of ratoon stunting disease. Cane Growers' Quarterly Bulletin. Brisbane, $38: 23-25$.

STEINDL, D.R.L., 1974b. Ratoon stunting disease history, distribution and control. In: XV Congress of the International Society of Sugar Cane Technologists, Durban, v.l, p. $210-212$.

STEINDL, D.R.L., 1976. The use of phase-contrast microscopy in the identification of ratoon stunting disease. In:XLIII Conference of the Queensland Society of Sugar Cane Technologists, Cairns, p. 71-72.

STEINDL, D.R.L. e C.G. HUGHES, 1953. Ratoon stunting disease. Cane Growers' Quarterly Bulletin. Indooropilly, 16:79-95.

STEINER, G. e R. BYTHER, 1975. Control of RSD by serial hot water treatments. In: HAWAIIAN SUGAR PLANTERS 'ASSOCIATION, Honolulu. 1974 Annual Report. Honolulu, p. 49-50.

STEINER, G.W. e J.C. COMSTOCK, 1977. Reaction of varieties to 
ratoon stunting disease. In: HAWAIIAN SUGAR . PLANTERS' ASSOCIATION. Hawaii. Annual Report 1976. Hawaii, p. 5859.

SUDo, S., 1980. Bactérias associadas ao raquitismo das soquei ras da cana-de-açücar (Saccharum sp.) e avaliação do capim elefante (Pennisetum purpureum Schum.) como indicadora. Piracicaba, ESALQ/USP, 86p. (Dissertação de Mestrado).

TEAKLE, D.S., 1974. The causal agent of sugarcane ratoon stunting disease (RSD). In: XV Congress of the Internation al Society of Sugar Cane Technologists, Durban, v.1, p.225233.

TEAKLE, D.S.; P.M. SMITH E D.R.L. STEINDL, 1973. Association of a small coryneform bacterium with the ratoon stunting disease of sugarcane. Journal of Agricultural Research. Lahore, 24:869-874.

TEAKLE, D.S.; P.M. SMITH e D.R.L. STEINDL, 1975. Ratoon stunt ing disease of sugarcane; possible correlation of resistance with vascular anatomy. Phytopathology. St. Paul, 65 $: 138-140$.

TEAKLE, D.S.; J.M. APPLETON e D.R.L. STEINDL, 1978a. An anatomical basis for resistance of sugar cane to ratoon stunting disease. Physiological Plant Pathology. New York, 12 :83-91.

TEAKLE, D.S.; R.G. BIRCH e J.M. APPLETON, 1978b. Use of sugarcane uprights in the diagnosis of RSD. Sugarcane Pathologists' Newsletter. Rēduit, (20):21.

THOMSON, G.M., 1958. The diseases of sugarcane in Natal. 
Bulletin of the South African Sugar Association. Mount Edgecombe, $(9): 1-11$.

TOKESHI, H., 1980. Doenças da cana-de-açücar. In: GALLI, F., coord. Manual de Fitopatologia. São Paulo, Editora Agronō mica Ceres, v. 2, cap. 12, p. 141-206.

TOKESHI, H.; A. SANGUINO e F. AKIBA, 1974. Xanthomonas albilineans, provāvel agente causal de raquitismo da soqueira e escaldadura da cana-de-acūcar. Piracicaba, ESALQ/USP, $17 p$. TOKESHI, H.; A.C.A. GHELLER; R.A. SORDI; Y. MASUDA E S. MATSU $\underline{0}$ KA, 1983. Nova unidade de tratamento térmico de toletes de cana-de-acúcar para controle do raquitismo da soqueira (RSD). Summa Phytopathologica. Piracicaba, 9:59-61. VALARINI, P.J., 1978. Avaliação da resistēncia ao raquitismo da soqueira pelo método da vazão de āgua em colmos de canade-açúcar. Piracicaba, ESALQ/USP, 78p. (Dissertação de Mestrado). 


\section{APENDI CE}

Apēndice 1. Análise de variância para os dados de produção de colmos por parcela (produtividade agrícola)

\begin{tabular}{lrcc}
\hline \multirow{2}{*}{ C. variaça } & GL & \multicolumn{2}{c}{ Quadrados médios } \\
\cline { 3 - 5 } & & Cana.planta & Cana soca \\
\hline Blocos & 5 & $18.747,41$ & $4.944,48$ \\
Variedades (V) & 2 & $61.079,63^{\star *}$ & $49.084,39 * \star$ \\
Tratamentos (T) & 2 & $29.758,80 * \star$ & $86.051,72^{\star \star}$ \\
VXT & 4 & $1.758,10$ & $4.507,78^{\star *}$ \\
Resíduo & 40 & $1.689,91$ & $1.246,94$ \\
\hline TOTAL & 53 & - & - \\
\hline
\end{tabular}


Apēndice 2. Anālise de variāncia para os dados de diāmetro médio dos colmos.

\begin{tabular}{lrccc}
\hline C. variaço & GL & \multicolumn{2}{c}{ Quadrados médios } \\
\cline { 4 - 5 } & & 5 & 5,3743 & 2,7799 \\
Blocos & 2 & 2,1309 & $3,8319^{\star \star}$ \\
Variedades (V) & 2 & $6,1508^{\star \star}$ & $7,6357^{\star \star}$ \\
Tratamentos (T) & 2 & 0,8960 & 0,0957 \\
VXT & 4 & 1,0450 & 0,5979 \\
Resíduo & 40 & & \\
\hline TOTAL & 53 & & \\
\hline
\end{tabular}

Apēndice 3. Anālise de variāncia para altura mëdia dos colmos

\begin{tabular}{lccc}
\hline \multirow{2}{*}{ C. variaço } & GL & \multicolumn{2}{c}{ Quadrados médios } \\
\cline { 3 - 4 } & & Cana planta & Cana soca \\
\hline Blocos & 5 & $2.335,10$ & 244,65 \\
Variedades $(V)$ & 2 & $329,85^{\star}$ & $2.747,63^{*}$ \\
Tratamentos $(T)$ & 2 & $1.245,91^{\star *}$ & $4.086,35^{*}$ \\
VXT & 4 & 174,66 & $375,18^{*}$ \\
Residuo & 40 & 83,55 & 138,38 \\
\hline Total & 53 & - & - \\
\hline
\end{tabular}


Apēndice 4. Anatise de variāncia para número de colmos industrializāveis por parcela

\begin{tabular}{lrrr}
\hline \multirow{2}{*}{ C. variacão } & GL & \multicolumn{2}{c}{ Quadrados médios } \\
\cline { 3 - 4 } & & Cana planta & Cana soca \\
\hline Blocos & 5 & $1.722,68$ & $1.392,60$ \\
Variedades $(V)$ & 2 & $70.437,02^{\star \star}$ & $144.314,24^{\star \star}$ \\
Tratamentos $(T)$ & 2 & 481,46 & $33.206,91^{\star *}$ \\
VXT & 4 & $1.317,16$ & $6.484,85$ \\
Residuo & 40 & 571,41 & $2.919,81$ \\
\hline TOTAL & 53 & - & - \\
\hline
\end{tabular}




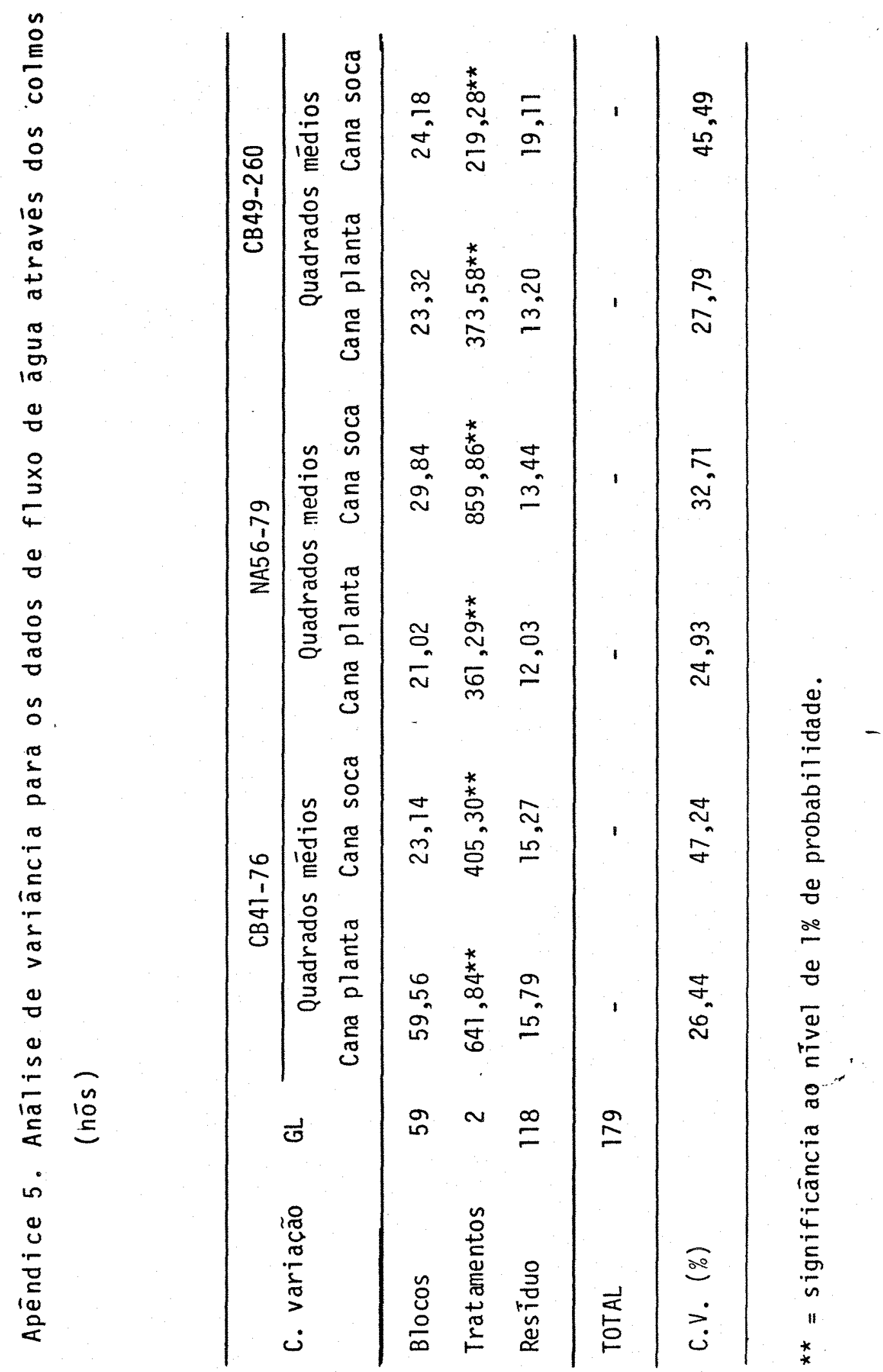


Apēndice 6. Dados originais de campo para diversas avaliacões da variedade CB41-76

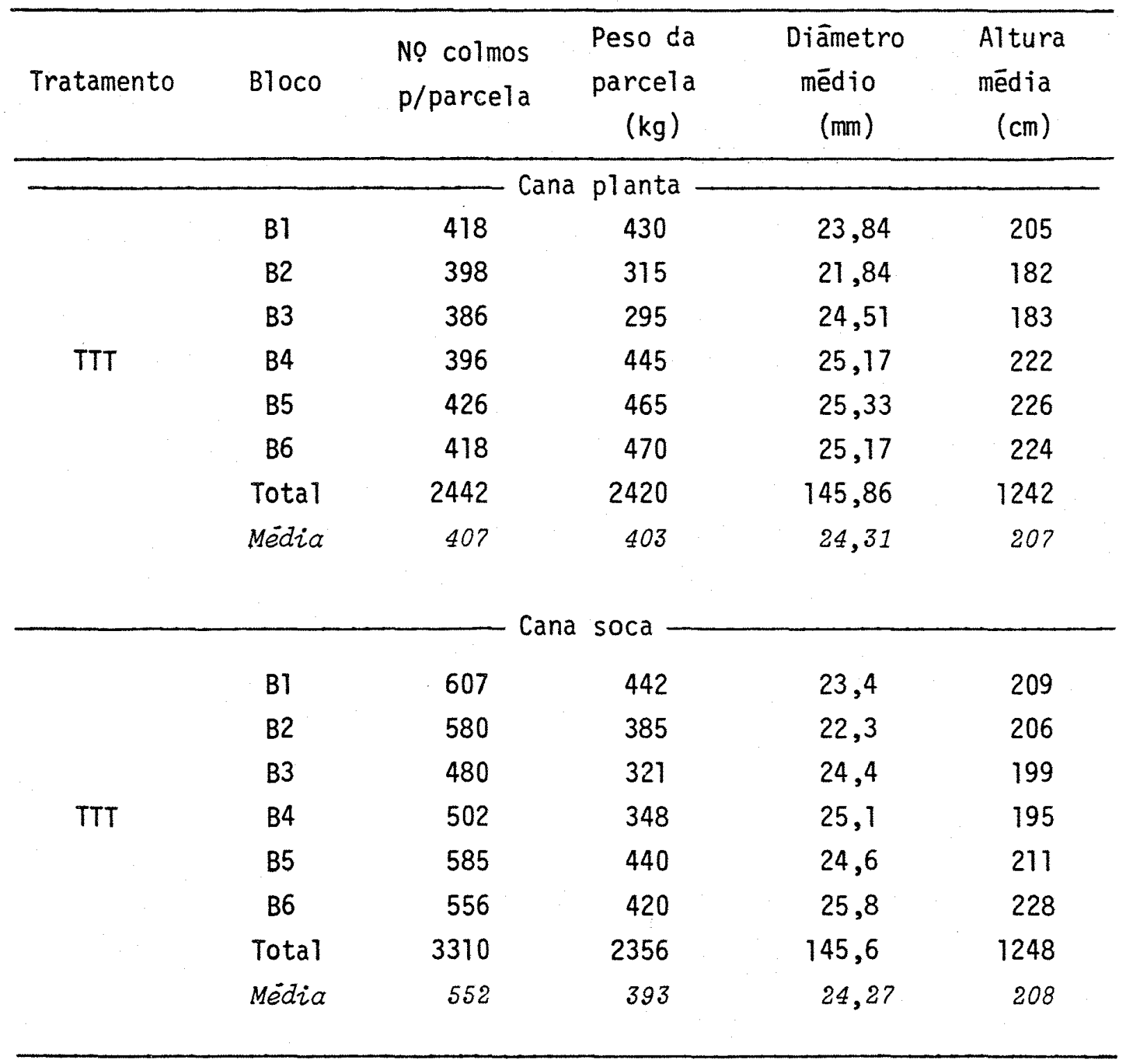

TTT - Tratamento térmico de toletes de 3 gemas. 
Apēndice 6. Continuação

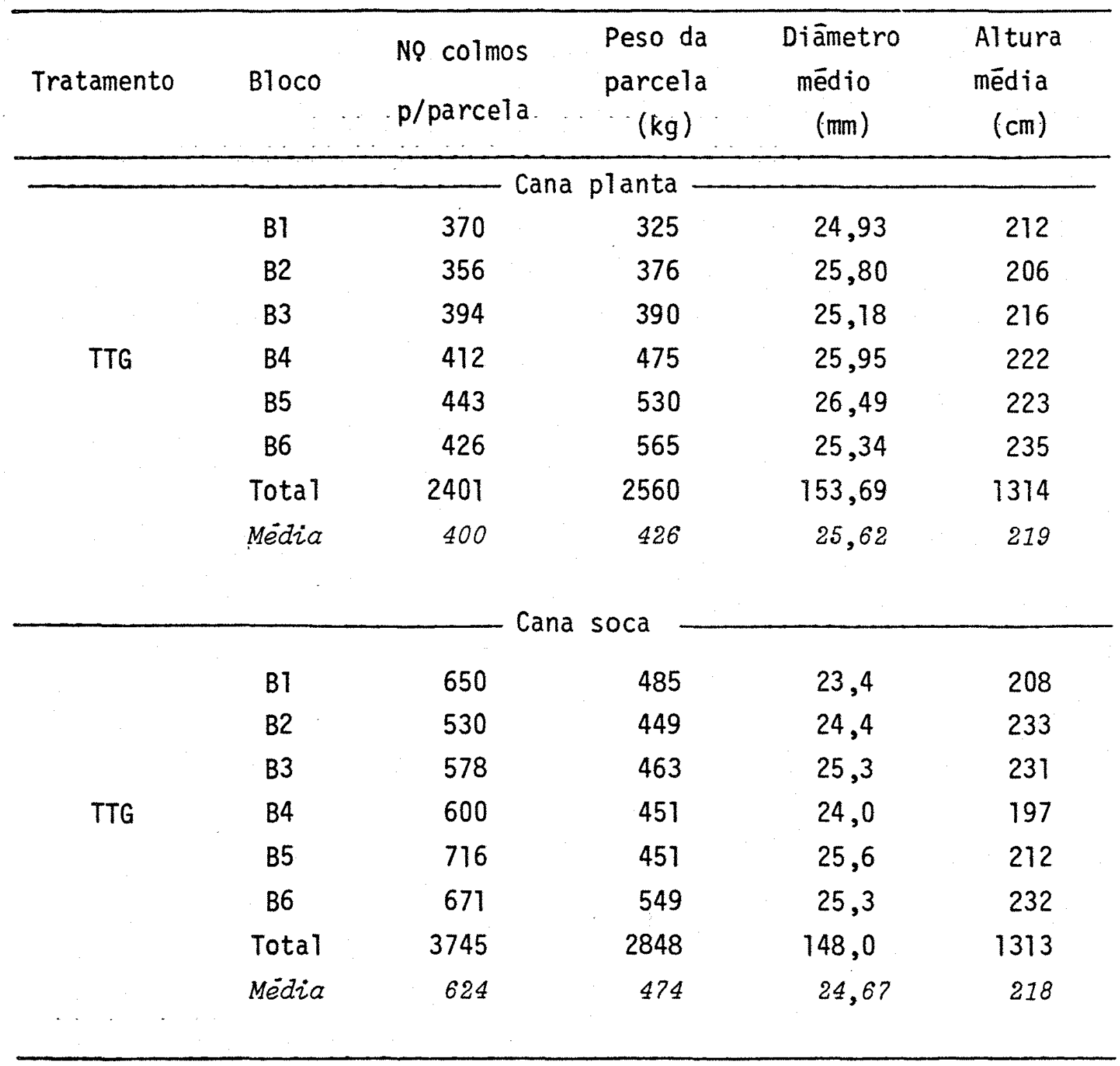

TTG - Tratamento térmico de gemas isoladas. 
Apēndice 6. Continuação

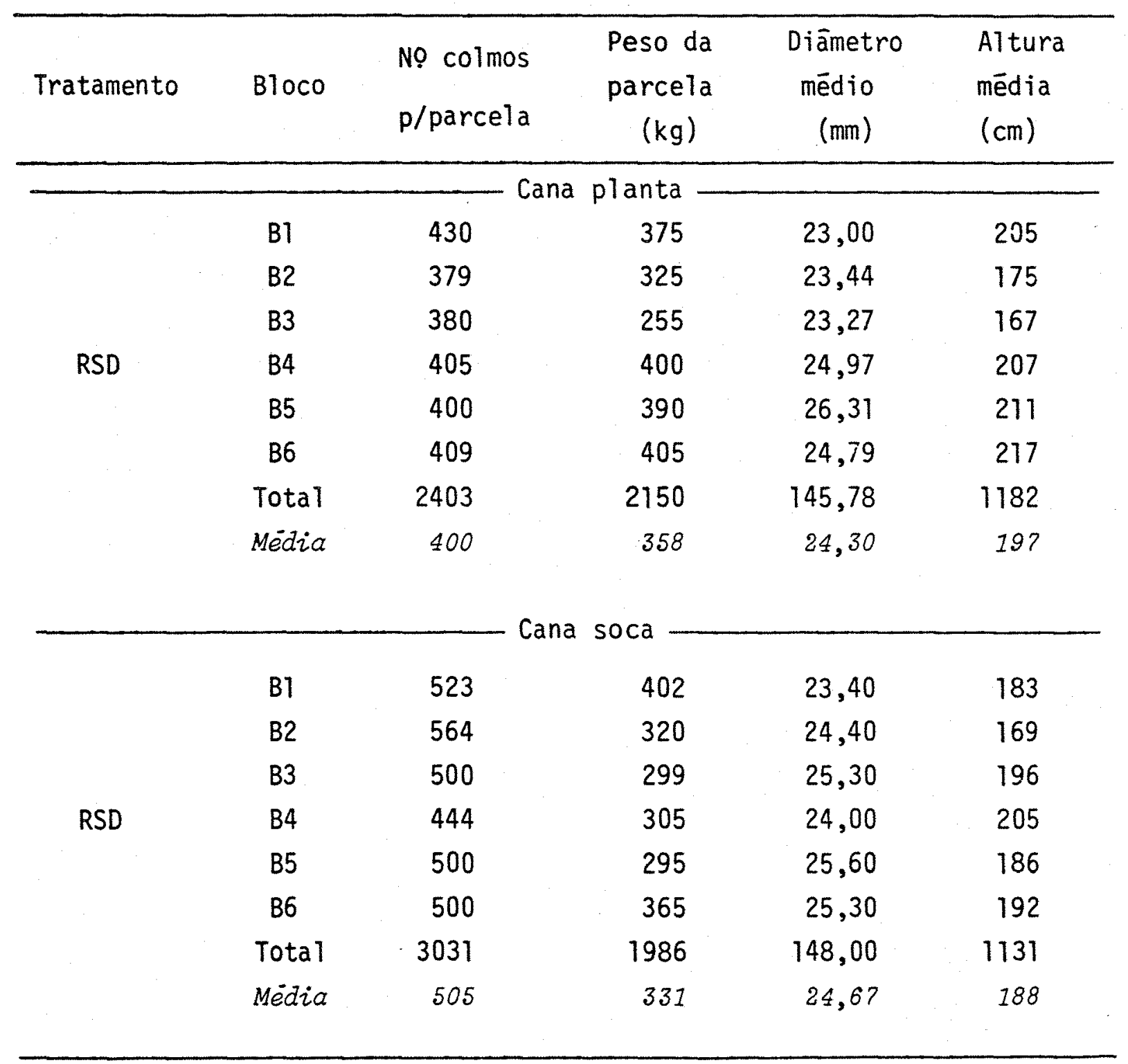

RSD - Raquitismo da soqueira. 
Apêndice 7. Dados origina is de campo para diversas avaliacões da variedade NA56-79

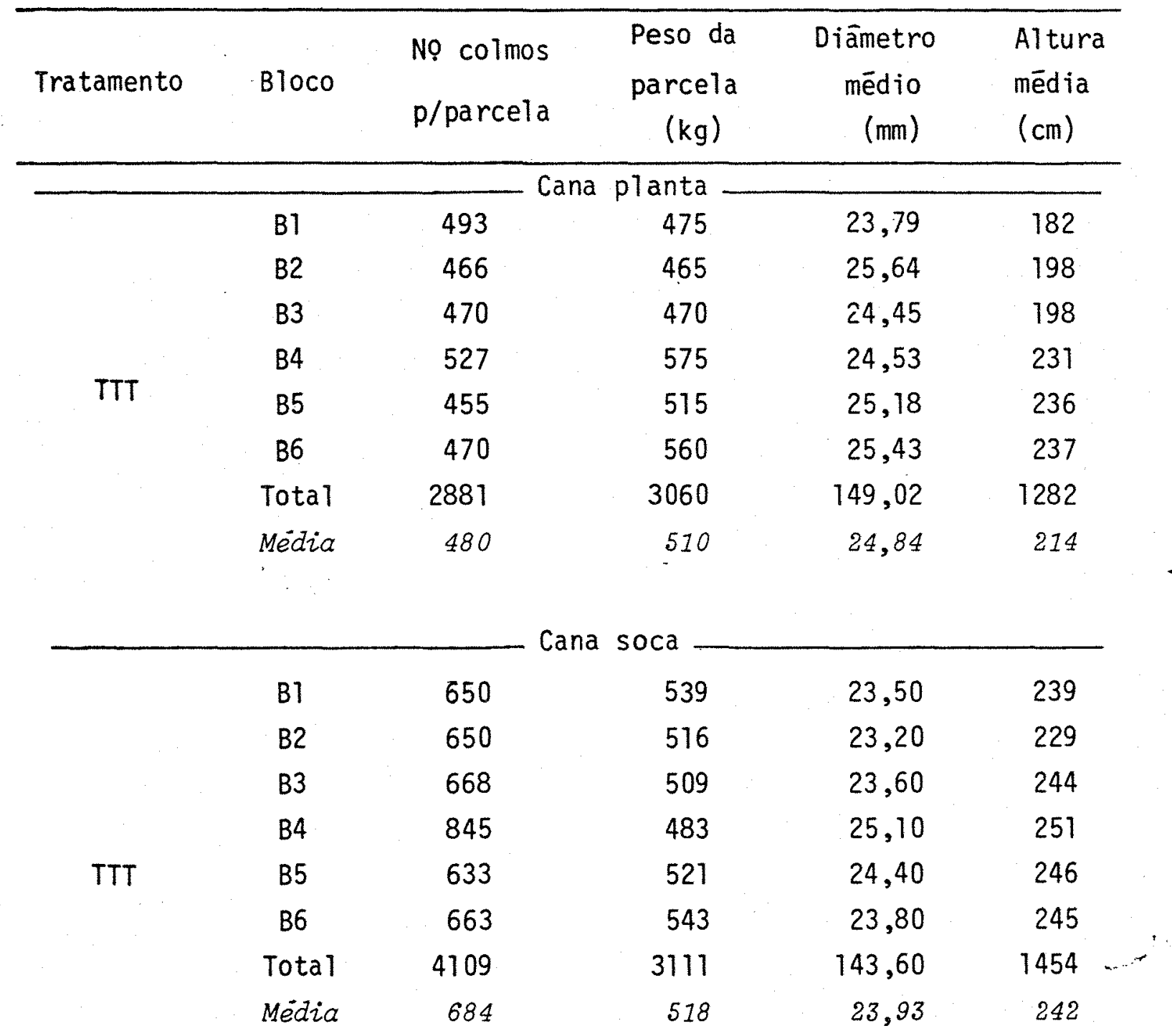

TTT - Tratamento térmico de toletes de 3 gemas. Continua... 
Apêndice 7. Continuação

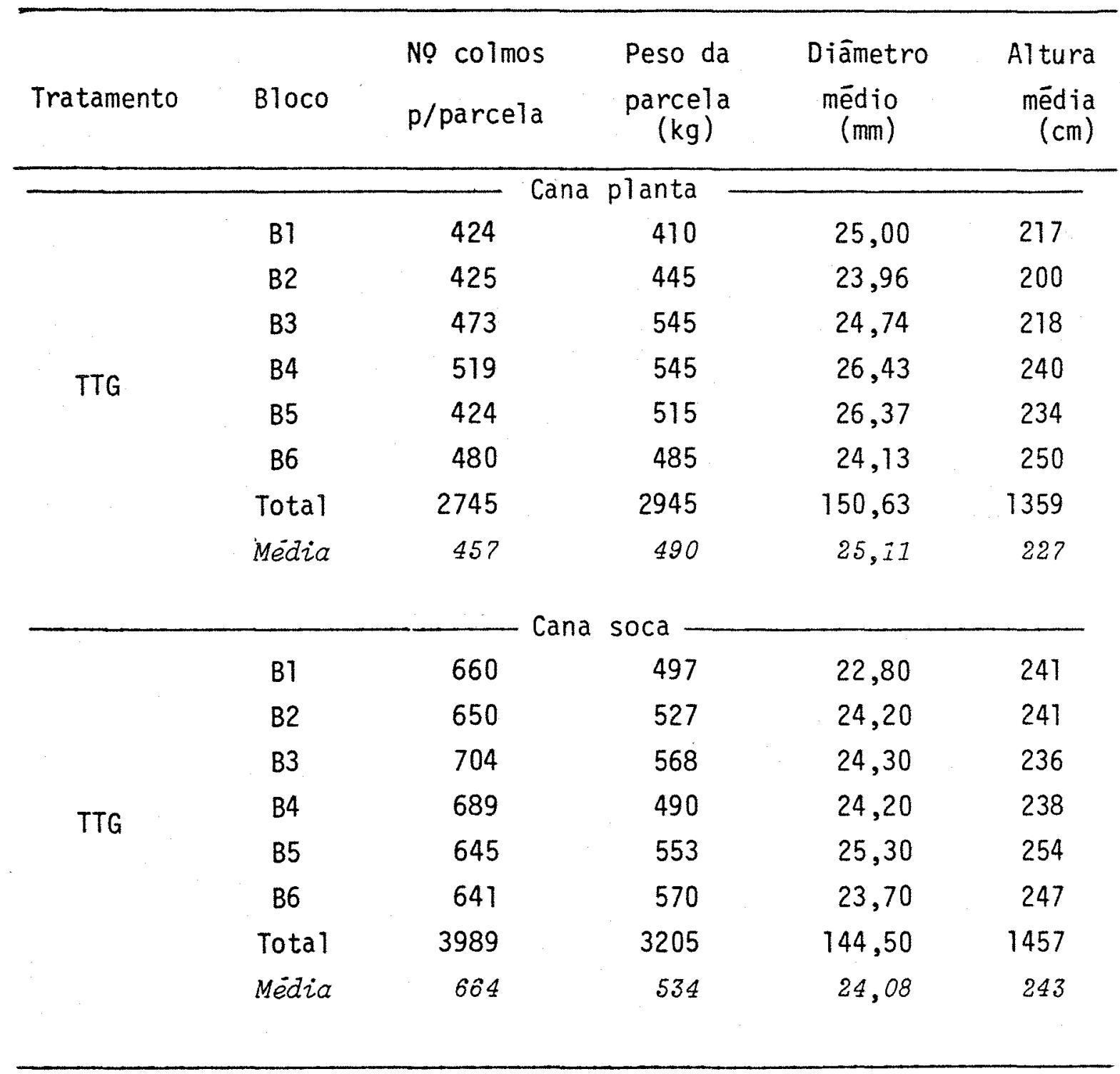

TTG - Tratamento térmico de gemas isoladas. 
Apēndice 7 . Continuação

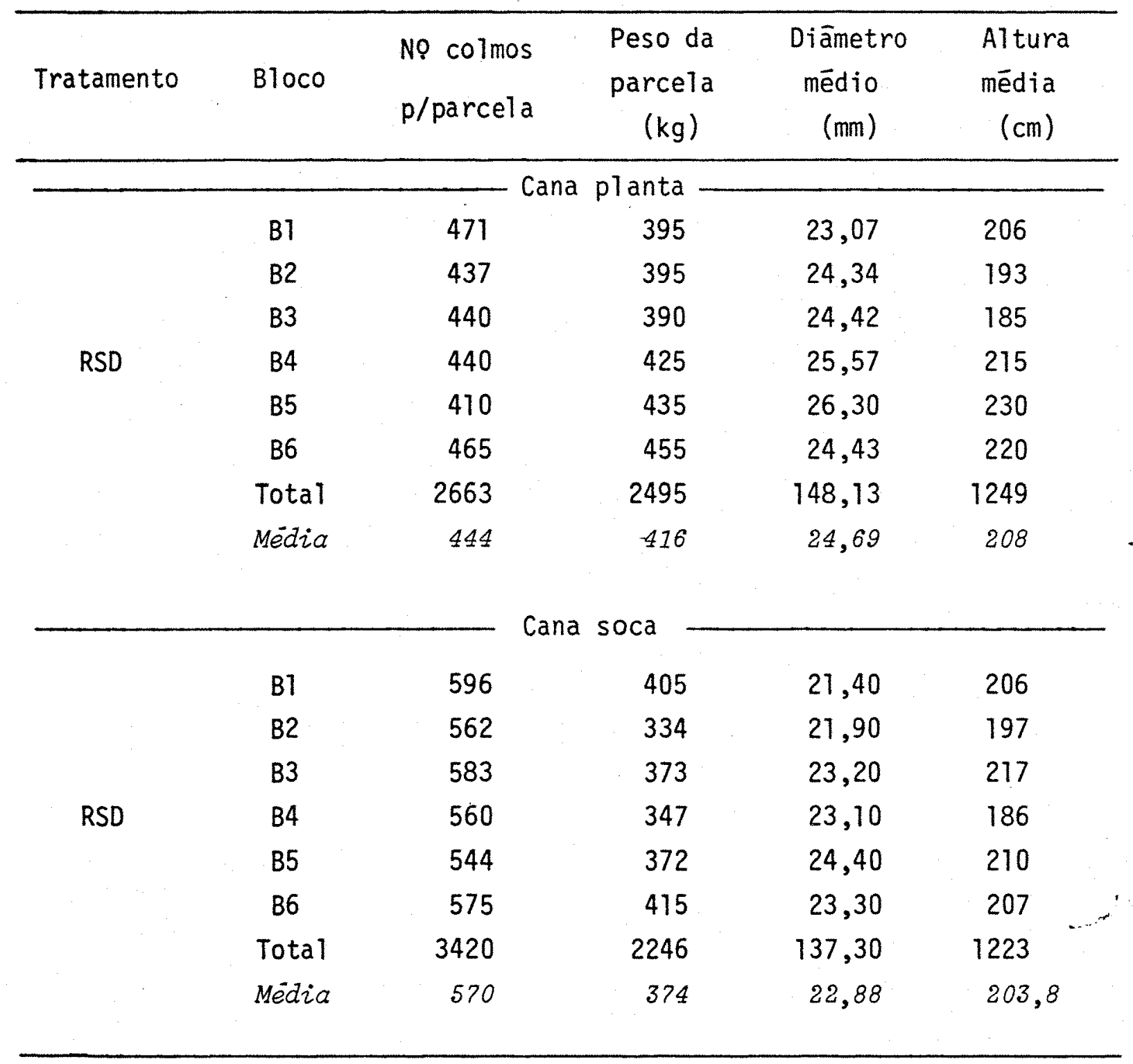

RSD - Raquitismo da soqueira. 
Apēndice 8. Dados originais de campo para diversas avaliaços da variedade CB49-260

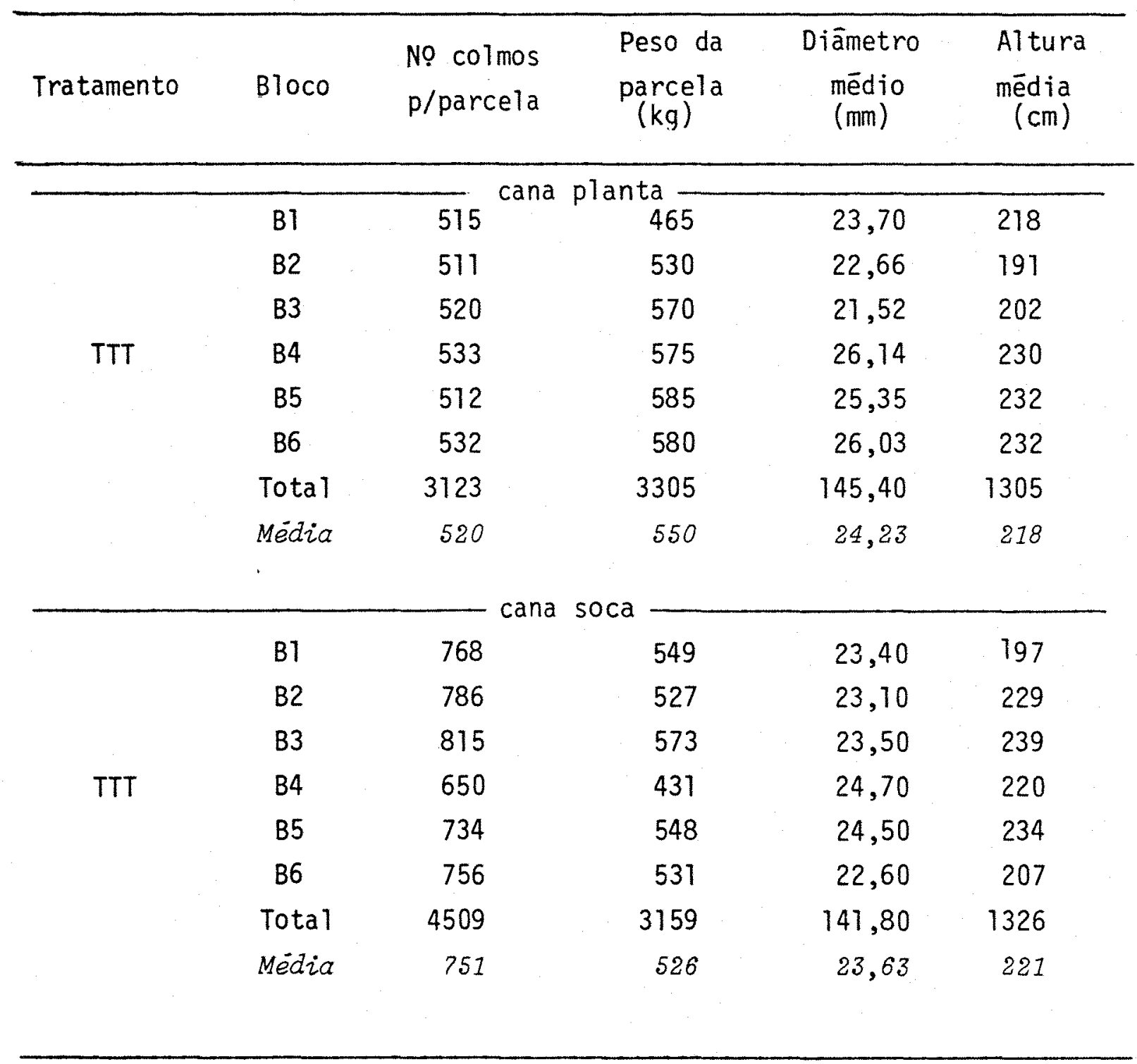

TTT - Tratamento térmico de toletes de 3 gemas.

Continua... 
Apêndice 8. Continuação

\begin{tabular}{|c|c|c|c|c|c|}
\hline Tratamento & Bloco & $\begin{array}{l}\text { Nọ colmos } \\
\text { p/parcela }\end{array}$ & $\begin{array}{l}\text { Peso da } \\
\text { parcela } \\
(\mathrm{kg})\end{array}$ & $\begin{array}{c}\text { Diāmetro } \\
\text { médio } \\
\text { (mm) }\end{array}$ & $\begin{array}{l}\text { Altura } \\
\text { mēdia } \\
(\mathrm{cm})\end{array}$ \\
\hline & & can & planta & & \\
\hline & $\mathrm{BI}$ & 516 & 480 & 27,07 & 212 \\
\hline & B2 & 480 & 445 & 24,38 & 207 \\
\hline & B3 & 551 & 530 & 22,67 & 179 \\
\hline \multirow[t]{8}{*}{ TTG } & B4 & 532 & 535 & 26,38 & 234 \\
\hline & B5 & 541 & 585 & 25,79 & 225 \\
\hline & $B 6$ & 498 & 520 & 24,07 & 214 \\
\hline & Total & 3118 & 3095 & 150,36 & 1271 \\
\hline & Média & 519 & 515 & 25,06 & 212 \\
\hline & B1 & 739 & 520 & 22,80 & 229 \\
\hline & B2 & 745 & 554 & 24,20 & 232 \\
\hline & B3 & 818 & 549 & 24,30 & 218 \\
\hline \multirow[t]{5}{*}{ TTG } & B4 & 640 & 465 & 24,20 & 199 \\
\hline & B5 & 813 & 612 & 25,30 & 227 \\
\hline & $B 6$ & 731 & 505 & 23,70 & 206 \\
\hline & Total & 4486 & 3205 & 144,50 & 1311 \\
\hline & Média & 747 & 534 & 24,08 & 218 \\
\hline
\end{tabular}

TTG - Tratamento tērmico de gemas isoladas. 
Apêndice 8. Continuação

\begin{tabular}{|c|c|c|c|c|c|}
\hline Tratamento & Bloco & $\begin{array}{l}\text { No colmos } \\
\text { p/parcela }\end{array}$ & $\begin{array}{c}\text { Peso da } \\
\text { parcela } \\
(\mathrm{kg})\end{array}$ & $\begin{array}{l}\text { Diāmetro } \\
\text { mëdio } \\
(\mathrm{mm})\end{array}$ & $\begin{array}{l}\text { Altura } \\
\text { média } \\
(\mathrm{cm})\end{array}$ \\
\hline & & $-\mathrm{Ca}$ & planta & 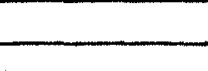 & 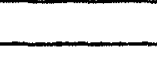 \\
\hline \multirow{8}{*}{ RSD } & B1 & 566 & 410 & 22,72 & 187 \\
\hline & B2 & 518 & 415 & 22,22 & 190 \\
\hline & B3 & 510 & 380 & 24,57 & 194 \\
\hline & B4 & 586 & 590 & 23,35 & 211 \\
\hline & B5 & 559 & 530 & 23,30 & 210 \\
\hline & B6 & 516 & 465 & 24,12 & 224 \\
\hline & Total & 3255 & 2790 & 140,28 & 1216 \\
\hline & Média & 543 & 465 & 23,38 & 203 \\
\hline \multirow{8}{*}{ RSD } & B1 & 700 & 418 & 21,50 & 209 \\
\hline & B2 & 729 & 468 & 22,60 & 201 \\
\hline & B3 & 720 & 456 & 24,40 & 226 \\
\hline & B4 & 705 & 412 & 21,50 & 188 \\
\hline & B5 & 782 & 483 & 23,10 & 211 \\
\hline & B6 & 672 & 388 & 21,30 & 198 \\
\hline & Total & 4308 & 2625 & 134,40 & 1233 \\
\hline & Média & 718 & 438 & 22,40 & 205,5 \\
\hline
\end{tabular}

RSD - Raquitismo da soqueira. 
Apêndice 9. Precioitação nos anos de 1983 a 1985 na Estação Ex perimental de Cana-de-Açūcar do IAA/PLANALSUCAR em Araras-SP

\begin{tabular}{lcccc}
\hline Més & 1983 & 1984 & 1985 & $\bar{M} 3$ anos \\
\hline Janeiro & 300,0 & 101,8 & 333,2 & 238,5 \\
Fevereiro & 354,6 & 34,0 & 144,6 & 205,6 \\
Marco & 375,6 & 70,2 & 113,2 & 169,1 \\
Abri1 & 105,0 & 92,0 & 174,8 & 61,4 \\
Maio & 192,8 & 26,8 & 34,8 & 46,4 \\
Junho & 104,1 & 0,0 & 20,6 & 36,4 \\
Jutho & 55,2 & 3,0 & 0,0 & 24,5 \\
Agosto & 0,0 & 161,2 & 9,4 & 27,9 \\
Setembro & 255,6 & 77,0 & 33,6 & 59,4 \\
Outubro & 103,8 & 24,4 & 3,6 & 133,3 \\
Novembro & 118,8 & 152,8 & 184,2 & 146,8 \\
Dezembro & 329,8 & 187,6 & 157,0 & 229,4 \\
\hline Total & $2.295,3$ & 930,8 & $1.209,0$ & $1.78,7$ \\
\hline
\end{tabular}

